\title{
Deactivation of a Single-Site Gold-on-Carbon Acetylene Hydrochlorination Catalyst: An X-ray Absorption and Inelastic Neutron Scattering Study
}

G. Malta, ${ }^{\dagger}$ S. A. Kondrat, ${ }^{\dagger,}{ }^{\ddagger}$ S. J. Freakley, ${ }^{\dagger}$ C. J. Davies, ${ }^{\dagger}$ S. Dawson, ${ }^{\dagger}$ X. Liu, ${ }^{\S}$ L. Lu, ${ }^{\| \odot}$ K. Dymkowski, ${ }^{\perp}$ F. Fernandez-Alonso, ${ }^{\#, \nabla}$ S. Mukhopadhyay, ${ }^{\#, \bigcirc}$ E. K. Gibson, $\triangle \triangle^{\circ}$ P. P. Wells, $\square, \square$ S. F. Parker, ${ }^{\#}$ C. J. Kiely, ${ }^{\dagger, \|}$ and G. J. Hutchings*, ${ }^{*}{ }^{\dagger}$

${ }^{\dagger}$ Cardiff Catalysis Institute, School of Chemistry, Cardiff University, Main Building, Park Place, Cardiff, CF10 3AT, United Kingdom

${ }^{\ddagger}$ Department of Chemistry, Loughborough University, Loughborough, Leicestershire LE113TU, United Kingdom

${ }^{\S}$ SynCat@Beijing Synfuels China Compnay Limited, 1 Leyuan 2 South Street, Section C, Yanqi Economic Development Area, Beijing, 101407, People's Republic of China

"Department of Materials Science and Engineering, Lehigh University, 5 East Packer Avenue, Bethlehem, Pennsylvania 18015, United States

${ }^{\perp}$ Scientific Computing Department, Rutherford Appleton Laboratory, Chilton, Didcot, Oxfordshire OX11 0QX, United Kingdom

\#ISIS Facility, STFC Rutherford Appleton Laboratory, Chilton, Didcot, Oxon OX11 0QX, United Kingdom

${ }^{\nabla}$ Department of Physics and Astronomy, University College London, Gower Street, London WC1E 6BT, United Kingdom

ODepartment of Materials, Imperial College London, Exhibition Road, London SW7 2AZ, United Kingdom

UK Catalysis Hub, Research Complex at Harwell, RAL, Oxford OX11 0FA, United Kingdom

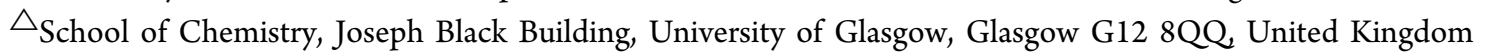

$\square$ School of Chemistry, University of Southampton, Southampton SO17 1BJ, United Kingdom

- Diamond Light Source, Harwell Science and Innovation Campus, Chilton, Didcot OX11 0DE, United Kingdom

Supporting Information

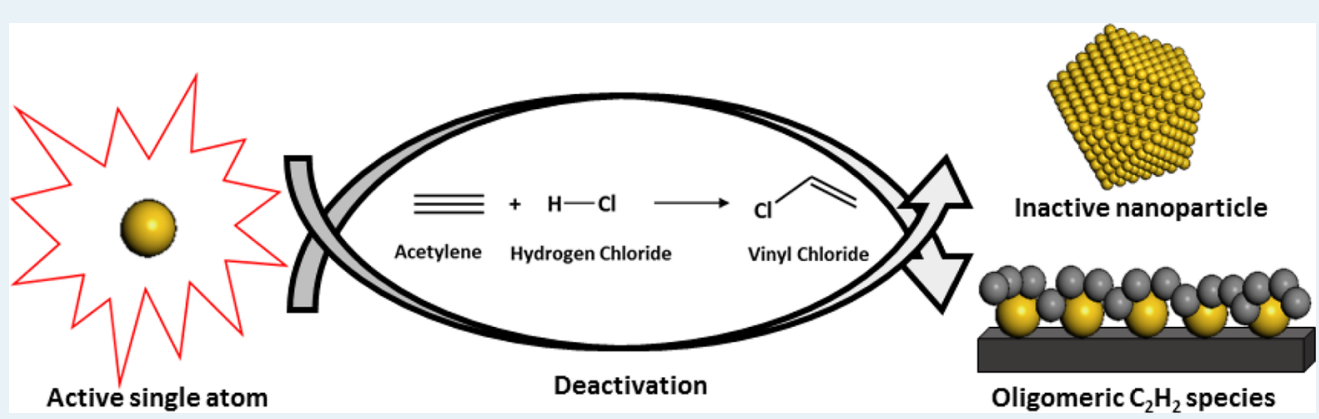

ABSTRACT: Single-site Au species supported on carbon have been shown to be the active sites for acetylene hydrochlorination. The evolution of these single-site species has been monitored by $\mathrm{Au} \mathrm{L}_{3} \mathrm{X}$-ray absorption spectroscopy (XAS). Alternating between a standard reaction mixture of $\mathrm{HCl} / \mathrm{C}_{2} \mathrm{H}_{2}$ and the single reactants has provided insights into the reaction mechanism and catalyst deactivation processes. We demonstrate that oxidative addition of $\mathrm{HCl}$ across an Au(I) chloride species requires concerted addition with $\mathrm{C}_{2} \mathrm{H}_{2}$, in accordance with both the XAS measurements of Au oxidation state and the reaction kinetics being first order with respect to each reactant. Excess $\mathrm{C}_{2} \mathrm{H}_{2}$ changes the Au speciation and results in the formation of oligomeric acetylene species which were detected by inelastic neutron scattering. Catalyst deactivation at extended reaction times can be correlated with the formation of metallic $\mathrm{Au}$ particles. These $\mathrm{Au}(0)$ species generated during the sequential gas experiments, or after prolonged reaction times, results in the analysis of the normalized near-edge white line intensity becoming an unsuitable guide for identifying the active Au species, affecting the strong correlation between normalized white line height and VCM productivity usually observed in the active catalyst. Thus, a combination of scanning transmission electron continued... 
microscopy and detailed modeling of whole XAS spectrum was required to distinguish active $\mathrm{Au}(\mathrm{I})$ and $\mathrm{Au}(\mathrm{III})$ species from the spectator $\mathrm{Au}(0)$ component.

KEYWORDS: acetylene hydrochlorination, gold catalysis, heterogeneous catalysis, single-site catalysis, deactivation

\section{INTRODUCTION}

Vinyl chloride monomer (VCM) is a large-scale chemical intermediate used almost exclusively as a precursor to polyvinyl chloride (PVC). Annually over 13 million tons of VCM are produced by acetylene hydrochlorination. Traditionally, acetylene hydrochlorination has been catalyzed using mercuric chloride supported on high surface area activated carbon. While this catalyst is highly active and has been industrially employed for several decades, it is extremely volatile and highly toxic. ${ }^{1-4}$ Following the prediction of Hutchings in 1985 that Au would be an effective catalyst for the reaction based on a correlation with electron affinity, ${ }^{5} \mathrm{Au}$ supported on carbon has recently been validated as a replacement catalyst for this large-scale industrial process. ${ }^{6}$

The preparation method for making the $\mathrm{Au} / \mathrm{C}$ catalysts has been demonstrated to strongly influence the corresponding structure and activity of the catalyst. ${ }^{7-9}$ Active catalysts were prepared by the impregnation of $\mathrm{HAuCl}_{4}$ onto $\mathrm{C}$ in strongly oxidizing solutions of nitric acid or aqua regia, while it was found that using an aqueous $\mathrm{HAuCl}_{4}$ solution produced catalysts with low activity. Characterization of these catalysts by a range of techniques, including X-ray photoelectron spectroscopy (XPS) and scanning transmission electron microscopy (STEM), suggested that the active catalysts had high Au dispersion and contained both oxidized $\mathrm{Au}$ (III) and $\mathrm{Au}(\mathrm{I})$ species. While these catalyst structure-activity studies revealed the importance of cationic Au species, the exact distribution of oxidation states and their chemical nature proved difficult to determine. First, XPS and STEM analyses can easily alter the relative distributions of $\mathrm{Au}(0), \mathrm{Au}(\mathrm{I})$, and $\mathrm{Au}(\mathrm{III})$ species and can induce the formation of nanoparticles in the samples through beam modification. ${ }^{10-15}$ Second, the reaction occurs under an aggressive chemical environment which can cause dynamic changes to the catalyst structure during reaction.

Recently, we reported the first detailed in situ X-ray absorption spectroscopy characterization study following the behavior of these $\mathrm{Au} / \mathrm{C}$ catalysts during the acetylene hydrochlorination reaction. ${ }^{9}$ Analysis of the $\mathrm{Au}_{3}$-edge $\mathrm{X}$-ray absorption near-edge structure (XANES) and the extended X-ray absorption fine structure (EXAFS) showed the operating catalyst comprised of atomically dispersed cationic species with no Au nanoparticles being present in the most active $\mathrm{Au} / \mathrm{C}$ catalysts. During the reaction, distinct changes in the XANES were observed, which clearly correlated to the catalyst productivity, showing that the active catalysts were comprised of atomically dispersed cationic gold in both $\mathrm{Au}(\mathrm{III})$ and $\mathrm{Au}(\mathrm{I})$ oxidation states. While this provided new details of the nature of the active catalyst under operating conditions, we reason that studying the deactivation of the catalyst will provide a more profound understanding of the catalytic behavior and the reaction mechanism to generate the information needed to design catalysts that exhibit extended lifetimes under industrial operating conditions.

Previously, from post-reaction ex situ XRD and Mössbauer spectroscopy studies, deactivation of such $\mathrm{Au} / \mathrm{C}$ catalysts operating above $120{ }^{\circ} \mathrm{C}$ has been attributed to the reduction of gold from its cationic form to generate metallic $\mathrm{Au}$ nanoparticles. ${ }^{16,17}$ Also, the formation of polymeric organic species on the catalyst surfaces, as observed after long reaction periods under industrial conditions, resulting in carbon fiber formation ${ }^{7}$ has been considered as a vector for the deactivation of this class of catalyst. Strategies to inhibit both deactivation pathways include the addition of other metal chlorides or dopants such as nitrogen and phosphorus. ${ }^{18,19}$

This study investigates if the formation of $\mathrm{Au}(0)$, which has previously been stated as a deactivation mechanism from postreaction studies, can be directly correlated with a decrease in VCM productivity under reaction conditions. ${ }^{16,20-23}$ In addition, the role of the individual reactants, in particular, acetylene, has been studied and correlated with the observed $\mathrm{Au}$ speciation, particularly the formation of polymeric organic species on the catalyst surface. ${ }^{7}$ In addition, observations of changes in $\mathrm{Au} \mathrm{L}_{3}$-edge XANES spectra during gas-switching experiments have been used to further elucidate the reaction mechanism.

\section{RESULTS AND DISCUSSION}

Catalyst Structure during Thermal Treatment. Highly active $\mathrm{Au} / \mathrm{C}$ catalysts prepared by the impregnation of $\mathrm{Au}$ from a solution of aqua regia have previously been shown to consist of atomically dispersed cationic $\mathrm{Au}$ and be highly active for acetylene hydrochlorination. ${ }^{9}$ To test the thermal stability of highly dispersed Au species, the catalyst was heated to $350{ }^{\circ} \mathrm{C}$ (at a rate of $5{ }^{\circ} \mathrm{C} / \mathrm{min}$ ) under an inert $\mathrm{N}_{2}$ atmosphere (to prevent the combustion of the carbon support) while being characterized using in situ XRD (Figure 1a). Given that the single-site cationic Au species, shown by XANES analysis ${ }^{9}$ to be present in catalyst, are undetectable by $\mathrm{XRD}$, no diffraction peaks from $\mathrm{Au}$ were observed at room temperature. The dispersed $\mathrm{Au}(\mathrm{III}) / \mathrm{Au}(\mathrm{I})$ species in the $1 \mathrm{wt} \% \mathrm{Au} / \mathrm{C}(1 \% \mathrm{Au} / \mathrm{C}-\mathrm{AR})$ catalyst showed high thermal stability from ambient temperature up to $250{ }^{\circ} \mathrm{C}$, with no characteristic reflections of fcc Au being observed over this temperature range. Upon reaching $300{ }^{\circ} \mathrm{C}$, reflections corresponding to the (111), (200), (220), and (310) Au lattice planes became evident, demonstrating the formation of discrete $\mathrm{Au}$ nanoparticles and implying that the $\mathrm{Au}$ species have now become mobile on the support material. Scherrer analysis of the (111) reflection at $300{ }^{\circ} \mathrm{C}$ gave an average crystallite size of $29 \mathrm{~nm}$. As expected, the mean nanoparticle size increased even further as the temperature was increased to $350{ }^{\circ} \mathrm{C}$ as did the relative intensity of the $\mathrm{Au}$ diffraction pattern, demonstrating that a greater amount of $\mathrm{Au}$ is in a crystalline state.

Clearly $1 \% \mathrm{Au} / \mathrm{C}-\mathrm{AR}$ is thermally stable from the perspective of XRD analysis up to $300{ }^{\circ} \mathrm{C}$ under an inert atmosphere. However, it should be noted that even if single-site cationic species are thermally stable under an inert atmosphere, there is significant scope for different $\mathrm{AuCl}_{x}$ species, which are not differentiable by XRD, to exist and evolve during heating. X-ray absorption fine structure (XAFS) can be used to show potential changes in $\mathrm{Au}$ oxidation state and speciation. Monitoring the changes in white line height, a feature detectable in the XANES region which corresponds to the $\mathrm{Au} 2 \mathrm{p}_{3 / 2} \rightarrow 5 \mathrm{~d}$ primary transition (see experimental section for more details), showed that while heating the catalyst to the reaction temperature $\left(200^{\circ} \mathrm{C}\right)$ under $\mathrm{Ar}$, the $\mathrm{Au}(\mathrm{III}) / \mathrm{Au}(\mathrm{I})$ ratio significantly changed from $\mathrm{Au}(\mathrm{III})$ chloride to $\mathrm{Au}(\mathrm{I})$ chloride (Figure $1 \mathrm{~b}){ }^{9}$ Therefore, while it is true to state single-site cationic species are retained on 

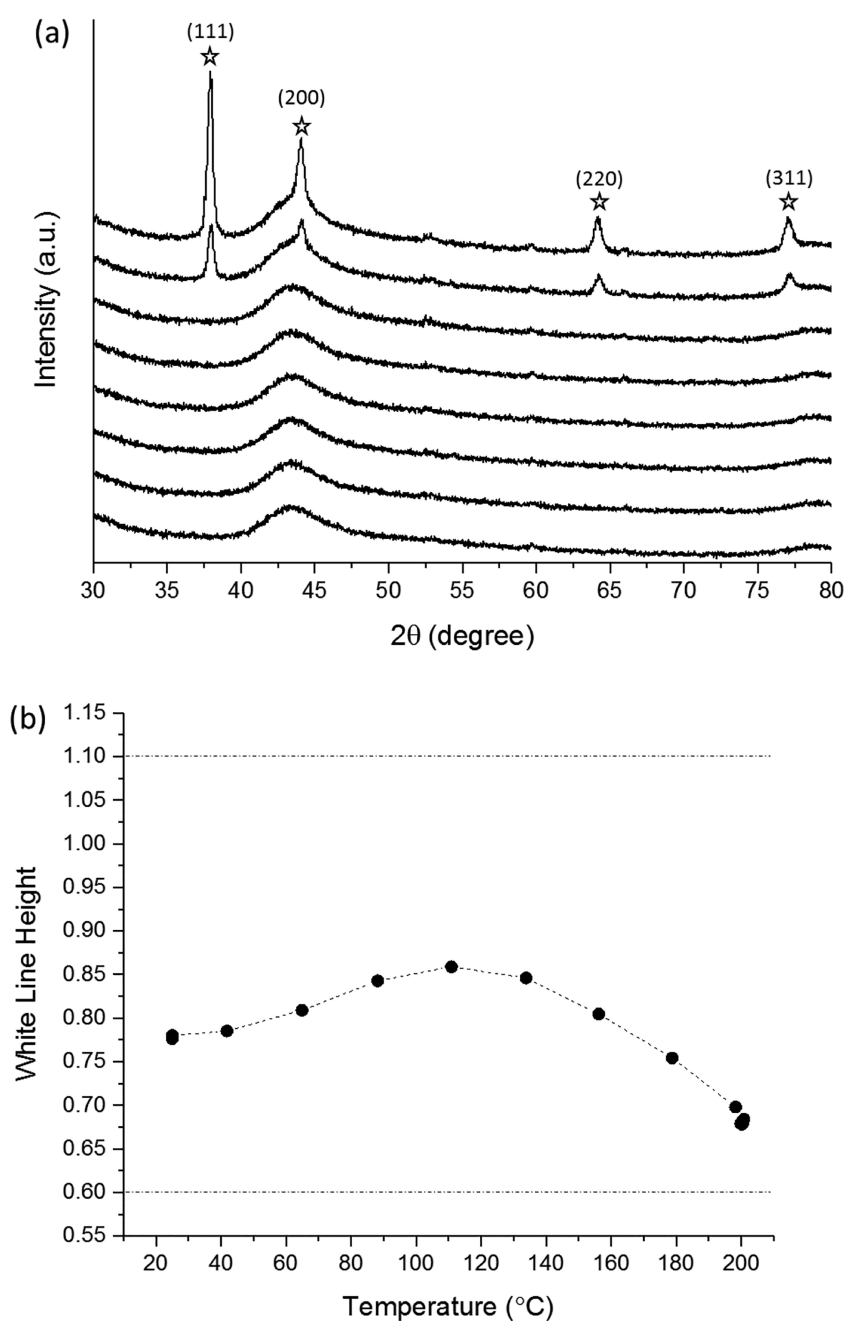

Figure 1. In situ characterization of the $1 \% \mathrm{Au} / \mathrm{C}$-AR. (a) Powder X-ray diffraction ( $\mathrm{pXRD}$ ) patterns acquired when increasing temperature under inert nitrogen atmosphere. (b) Changes in white line height during heating to reaction temperature $\left(200^{\circ} \mathrm{C}\right)$ under $\mathrm{Ar}$ at $5{ }^{\circ} \mathrm{C} \min ^{-1}$ (Dotted lines represent the white line intensities of the $\mathrm{Au}(\mathrm{I})\left[\mathrm{AuCl}_{2}\right]^{-}$standard (value of 0.6) and the $\mathrm{Au}(\mathrm{III}) \mathrm{KAuCl}_{4}$ standard (value of 1.1)).

heating, the speciation and oxidation state changes even in the absence of reactant gases.

XANES Analysis of Au/C-AR Catalyst under Different Reactant Gases. It has been postulated, based on combined in situ XAFS and DFT studies, that the reaction mechanism for $\mathrm{Au}$-catalyzed acetylene hydrochlorination proceeds via an oxidative addition and reductive elimination process to generate $\mathrm{VCM}$, which makes the redox properties of the cationic $\mathrm{Au}$ species an essential requirement for activity. ${ }^{7,9}$ Given the postulated redox mechanism and likely deactivation mechanism, namely, the agglomeration and reduction of cationic species to metallic $\mathrm{Au}$, it can be expected that exposure to the reaction mixture or indeed each individual reactant gas has the potential to affect Au speciation. In previous studies, ex situ XPS of Au/C catalysts collected after exposure to different combinations of reactants showed that $\mathrm{HCl}$ increased the concentrations of $\mathrm{Au}(\mathrm{III})$ and $\mathrm{Au}(\mathrm{I})$ at the expense of $\mathrm{Au}(0)$, while $\mathrm{C}_{2} \mathrm{H}_{2}$ resulted in a reduction of $\mathrm{Au}(\mathrm{III})$ to $\mathrm{Au}(\mathrm{I}) .^{7}$ To reiterate, these experiments were carried out ex situ, potentially resulting in significant changes to the Au speciation during removal from the reactor and exposure to air and moisture before insertion into the XPS instrument. Another important point to note is that relative changes in the concentrations $\mathrm{Au}(\mathrm{III})$ and $\mathrm{Au}(\mathrm{I})$ species appear minor in comparison to the dominant signal associated with $\mathrm{Au}(0)$. A key point to consider during XPS experiments is the significant photoreduction of gold chloride compounds that can occur, which results in overestimation of the $\mathrm{Au}(0)$ concentration. While appearing counterintuitive, the higher incident photon energy associated with $\mathrm{Au} \mathrm{L}_{3}$-edge XAFS (11.919 keV for $\mathrm{Au}_{3}$-edge XAFS versus $1.487 \mathrm{keV}$ for $\mathrm{Al}$ source $\mathrm{XPS}$ ) results in lower rates of photoreduction for XAFS experiments compared to Al source XPS due to the significantly lower absorption crosssection in the former case. ${ }^{9}$ For this reason XAFS can be considered a less artifact prone and more representative characterization technique for $\mathrm{Au}$ valence state determination than XPS.

To clarify the influence of both combinations and the individual reactants on $\mathrm{Au}$ speciation, under reaction conditions, a sequential flow in situ $\mathrm{Au} \mathrm{L}_{3}$-edge XAFS experiment (as detailed in the Experimental Section) was performed to study the 1\% $\mathrm{Au} / \mathrm{C}-\mathrm{AR}$ catalyst. A plot of VCM productivity with respect to reaction time and the normalized white line intensity is shown in Figure 2 during exposure to a well-defined sequence of different reaction gas mixtures.

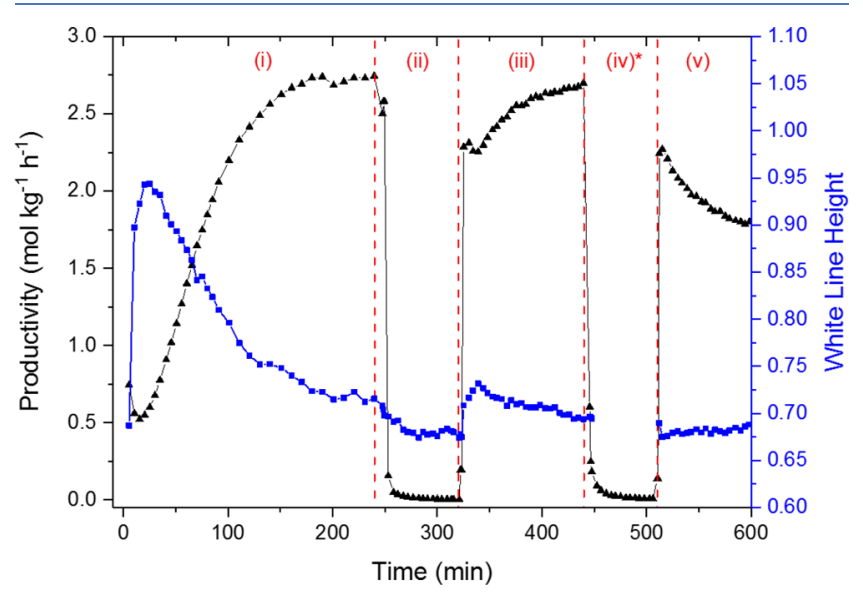

Figure 2. VCM productivity during the sequential gas exposure experiment combined with in situ $\mathrm{Au} \mathrm{L}_{3}$-edge XANES data of 1 wt \% $\mathrm{Au} / \mathrm{C}-\mathrm{AR}$. VCM production (black triangles) as a function of time online and the corresponding normalized white line intensity values (blue squares) derived from XANES measurements. Reaction sequences: (i) $\mathrm{HCl}+\mathrm{C}_{2} \mathrm{H}_{2} / \mathrm{Ar}$, (ii) $\mathrm{HCl} / \mathrm{Ar}$, (iii) second $\mathrm{HCl}+$ $\mathrm{C}_{2} \mathrm{H}_{2} / \mathrm{Ar}$, (iv) $\mathrm{C}_{2} \mathrm{H}_{2} / \mathrm{Ar}$, and (v) third $\mathrm{HCl}+\mathrm{C}_{2} \mathrm{H}_{2} / \mathrm{Ar}$ exposure. (*) No white line data is shown for step iv in the sequence.

The catalytic behavior of the $1 \% \mathrm{Au} / \mathrm{C}$-AR catalyst for the first 240 min under the reaction mixture shows the same trend as in our previous study in which an induction period of ca. $180 \mathrm{~min}$ was noted before VCM productivity reached steady state. During this induction period, the normalized $\mathrm{Au} \mathrm{L}_{3}$-edge white line intensity dramatically increased from 0.67 to 0.94 before slowly decreasing back to a value of 0.70 at steady state. As previously reported, ${ }^{9}$ this initial change in white line height is associated with the rapid formation of $\mathrm{Au}$ (III) chloride-like species followed by its gradual reduction to one principally containing $\mathrm{Au}(\mathrm{I})$ chloride.

After $240 \mathrm{~min}$ of reaction the catalyst was then exposed to $\mathrm{HCl}$ only diluted in argon [ $\mathrm{HCl} / \mathrm{Ar}]$ for ca. $70 \mathrm{~min}$ (i.e., no $\mathrm{C}_{2} \mathrm{H}_{2}$ ) at a flow rate matching the total flow of the reaction mixture. As expected, while flowing $\mathrm{HCl} / \mathrm{Ar}$ only, no vinyl chloride monomer formation was observed. Interestingly, in the 

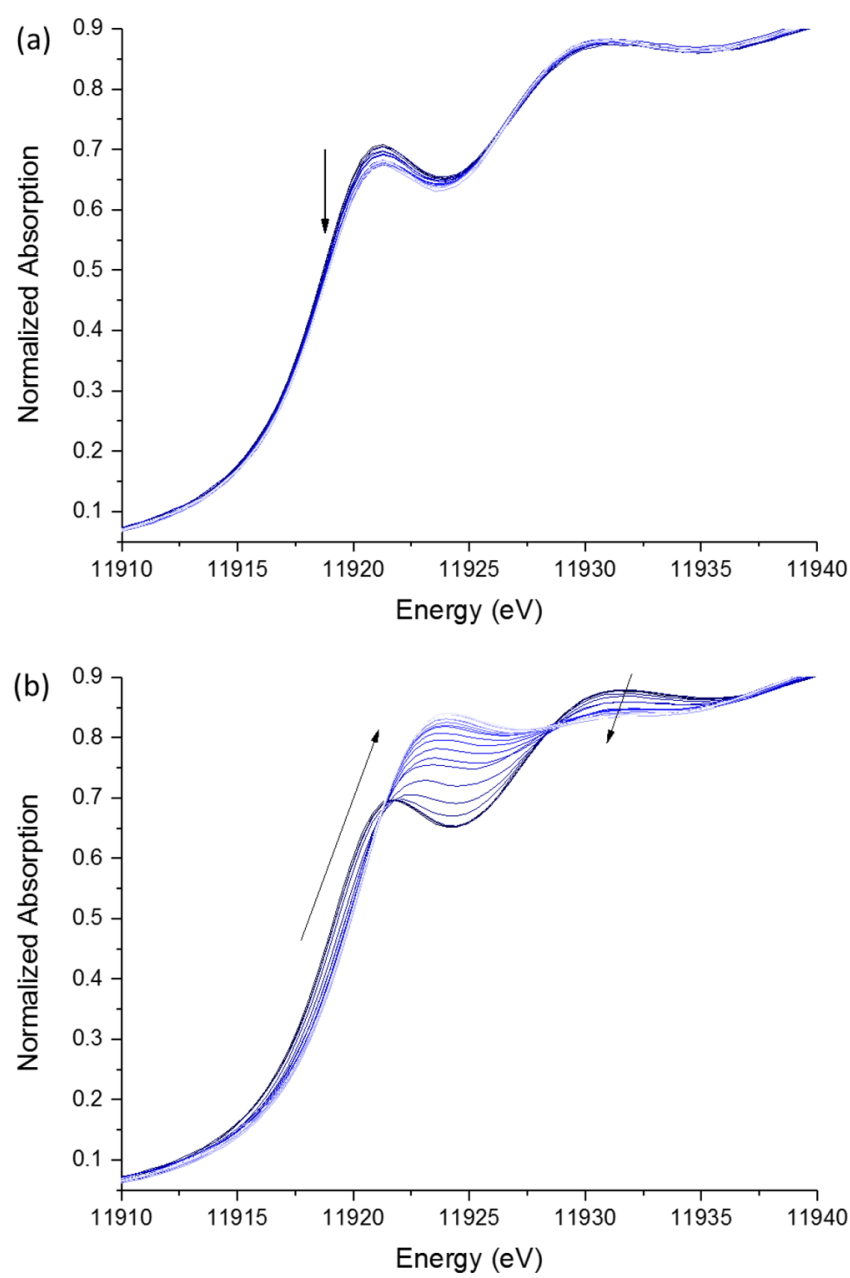

Figure 3. Evolution of XANES spectra during (a) step ii $(\mathrm{HCl} / \mathrm{Ar})$ and (b) step iv $\left(\mathrm{C}_{2} \mathrm{H}_{2} / \mathrm{Ar}\right)$.

XANES region (Figures 2 and $3 \mathrm{a}$ ) a small decrease in normalized white line height was noted (from 0.70 to 0.68 ), indicating a very slight reduction in $\mathrm{Au}$ oxidation state. The observed value of 0.68 is identical to that of the catalyst at $200{ }^{\circ} \mathrm{C}$ in an inert atmosphere. This observation at first sight appears contradictory to the postulate that $\mathrm{HCl}$ is the oxidant within the reaction, preventing Au reduction and also facilitating the first step of the reaction mechanism. Indeed, ex situ studies have shown $\mathrm{HCl}$ to have oxidized $\mathrm{Au}(0)$. However, in the context of oxidizing metallic $\mathrm{Au}$ the concentration of $\mathrm{HCl}$ employed here is significantly lower than in other studies, limiting the oxidation potential of the reaction environment and possibly explaining the lack of $\mathrm{Au}$ oxidation in the presence of $\mathrm{HCl}$ alone. ${ }^{7,16,24}$ Yet this consideration does not explain why a significant increase in normalized white line height is observed under a $\mathrm{HCl} / \mathrm{C}_{2} \mathrm{H}_{2}$ reaction mixture but not with $\mathrm{HCl} / \mathrm{Ar}$ alone.

Reintroduction of the full reaction mixture (i.e., $\mathrm{HCl} / \mathrm{C}_{2} \mathrm{H}_{2} / \mathrm{Ar}$ ), after $\mathrm{HCl} / \mathrm{Ar}$ treatment, resulted in an almost immediate return of VCM production (Figure 2), although initially at a marginally lower rate of $2.28 \mathrm{~mol} \mathrm{~kg}_{\mathrm{cat}}{ }^{-1} \mathrm{~h}^{-1}$ compared to the previous steadystate productivity rate of $2.74 \mathrm{~mol} \mathrm{~kg}^{-1} \mathrm{~h}^{-1}$. The VCM productivity then steadily increased over the next $115 \mathrm{~min}$ before reaching a new steady-state productivity value of $2.70 \mathrm{~mol} \mathrm{~kg}_{\text {cat }}{ }^{-1} \mathrm{~h}^{-1}$. During this period of increasing activity the normalized white line intensity also gradually increased. Clearly, the catalyst was not significantly deactivated under the $\mathrm{HCl} / \mathrm{Ar}$ atmosphere, although the system was perturbed and a second, albeit smaller, induction period was seen. As the $1 \% \mathrm{Au} / \mathrm{C}-\mathrm{AR}$ catalyst was not deactivated by the $\mathrm{HCl} / \mathrm{Ar}$ gas treatment but nether underwent oxidation, it is reasonable to conclude that $\mathrm{C}_{2} \mathrm{H}_{2}$ must somehow assist in the oxidative addition of $\mathrm{HCl}$, facilitating the reaction, based on the $\mathrm{Au}(\mathrm{I})-\mathrm{Au}(\mathrm{III})$ redox couple. We postulate that $\mathrm{C}_{2} \mathrm{H}_{2}$ assists in the oxidative addition of $\mathrm{HCl}$ in the first step of the reaction mechanism with a concerted $\mathrm{HCl}$ and $\mathrm{C}_{2} \mathrm{H}_{2}$ addition to the $\mathrm{Au}(\mathrm{I}) \mathrm{Cl}$ species. This differs from our previously proposed mechanism ${ }^{9}$ in which the oxidative addition of $\mathrm{HCl}$ to form $\mathrm{AuCl}_{2} \mathrm{H}$ was then followed by $\mathrm{C}_{2} \mathrm{H}_{2}$ addition and the reductive elimination of VCM. Further supporting evidence for this revised mechanism has been obtained by studying the order of reaction with respect to $\mathrm{HCl}$ and $\mathrm{C}_{2} \mathrm{H}_{2}$ (as discussed later).

Once the steady state in step iii of the sequence had been reached, the catalyst was exposed to dilute acetylene only [i.e., $\left.\mathrm{C}_{2} \mathrm{H}_{2} / \mathrm{Ar}\right]$ (step iv). In common with the $\mathrm{HCl} / \mathrm{Ar}$ environment, no VCM production was observed with exposure to acetylene alone. On introduction of $\mathrm{C}_{2} \mathrm{H}_{2} /$ Ar the XANES spectra (Figure 3b) were significantly altered, with the gradual loss of features at 11921 (white line) and $11931 \mathrm{eV}$ and the simultaneous appearance of a new feature at $11923 \mathrm{eV}$ along with the absorption edge shifting to higher energy. The new XANES spectra were not clearly attributable to either $\mathrm{Au}(\mathrm{III})$ or $\mathrm{Au}(\mathrm{I})$ chloride-like speciation. Figure 4 shows a comparison between $\mathrm{C}_{2} \mathrm{H}_{2} / \mathrm{Ar}$ XANES spectra

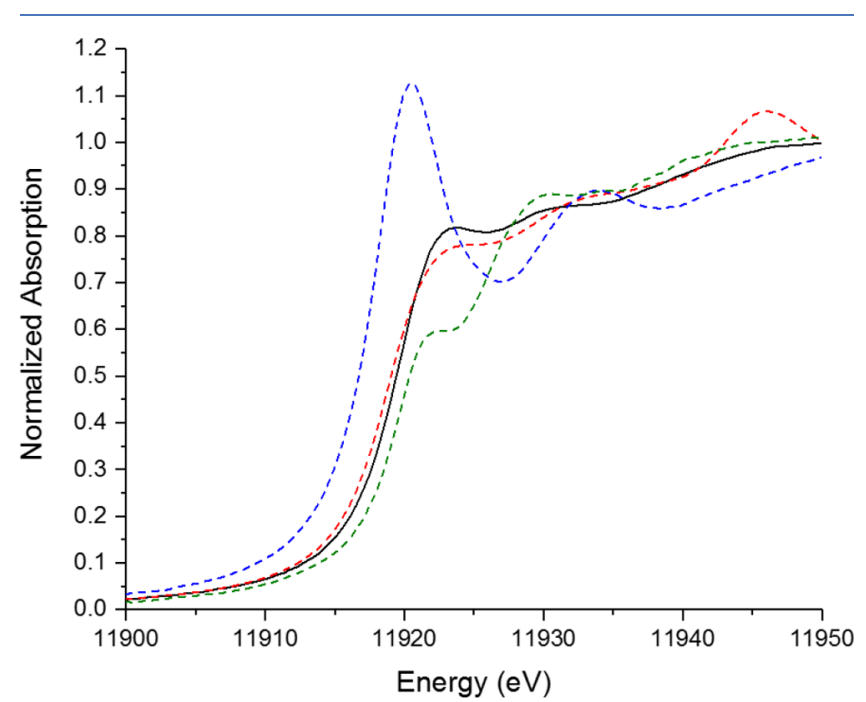

Figure 4. Comparison of $\mathrm{Au} \mathrm{L}_{3}$-edge XANES of the $1 \mathrm{wt} \% \mathrm{Au} / \mathrm{C}-\mathrm{AR}$ catalyst under an $\mathrm{C}_{2} \mathrm{H}_{2} / \mathrm{Ar}$ atmosphere to $\mathrm{Au}(\mathrm{III})$ chloride, $\mathrm{Au}(\mathrm{I})$ chloride, and a metal standard: (black solid line) $1 \mathrm{wt} \% \mathrm{Au} / \mathrm{C}-\mathrm{AR}$ catalysts under $\mathrm{C}_{2} \mathrm{H}_{2} / \mathrm{Ar}$, (blue dashed line) $\mathrm{Au}$ (III) standard of $\mathrm{KAuCl}_{4}$, (green dashed line) $\mathrm{Au}(\mathrm{I})$ standard of $\left[\mathrm{AuCl}_{2}\right]^{-}$, and (red dashed line) $\mathrm{Au}(0)$ metal foil.

and $\mathrm{Au}(\mathrm{III}), \mathrm{Au}(\mathrm{I})$, and $\mathrm{Au}(0)$ standards. Therefore, plotting normalized white line values as in Figure 2 was considered to be unsuitable to determine the Au speciation in this instance. Some similarities to the $\operatorname{Au}(0)$ standard can be observed for the new feature, although the absorption edge position is noticeably different. While a detailed analysis of this feature is not yet developed, it can be concluded that $\mathrm{C}_{2} \mathrm{H}_{2}$ strongly influences the observed XANES spectrum through significant changes in electron density at the Au metal center, as evidenced by the increase in the energy of the absorption edge position. Given that exposure of Au catalysts to acetylene without an excess of $\mathrm{HCl}$ is known to result in catalyst deactivation, ${ }^{6}$ the observed changes in the XANES spectra are evidence of a strong $\mathrm{Au}-\mathrm{C}_{2} \mathrm{H}_{2}$ 
interaction that is potentially detrimental to the catalytic performance. Further analysis of this species from EXAFS is presented in the following section.

Reintroduction of reactant gases to the $1 \% \mathrm{Au} / \mathrm{C}-\mathrm{AR}$ catalyst after $\mathrm{C}_{2} \mathrm{H}_{2} /$ Ar treatment (step v) resulted in VCM productivity returning. However, unlike the original induction period (step i) or following the $\mathrm{HCl} / \mathrm{Ar}$ treatment (step iii), the productivity did not increase with reaction time. Rather it decreased from 2.24 to $1.79 \mathrm{~mol} \mathrm{~kg}^{-1} \mathrm{~h}^{-1}$ over $90 \mathrm{~min}$, providing evidence that the $\mathrm{Au}$ acetylene interaction occurring in step iv had partially poisoned the catalyst. Interestingly, the XANES of the catalyst on reintroduction of $\mathrm{HCl} / \mathrm{C}_{2} \mathrm{H}_{2} / \mathrm{Ar}$ reactant gases in step $\mathrm{v}$ show an almost instantaneous return to the more recognizable spectrum with the characteristic a $\mathrm{Au}(\mathrm{I}) / \mathrm{Au}$ (III) features seen in the previous reaction steps $\mathrm{i}-\mathrm{iii}$. The re-emergence of an identifiable white line feature could therefore be monitored, whose intensity was found to remain relatively constant at $\sim 0.69$, with only a marginal increase in height over this final reaction period (Figure 2). Notably, the relationship between the normalized white line and VCM productivity was clearly altered relative to that observed initially and after $\mathrm{HCl} / \mathrm{Ar}$ treatment.

A linear correlation between the normalized white line height and VCM productivity for the initial induction period (step $\mathrm{i}$ in

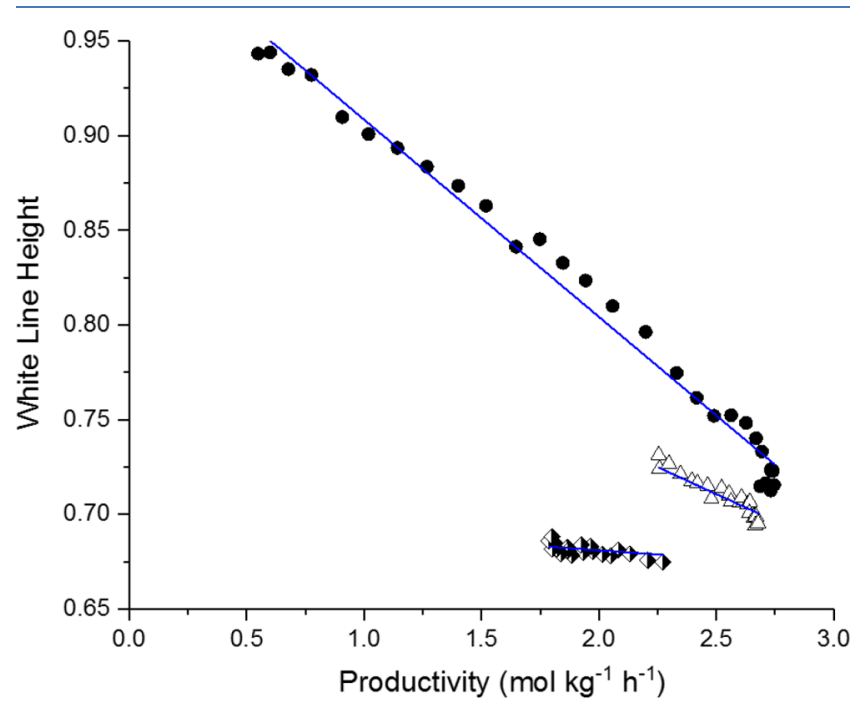

Figure 5. Comparison of white line height versus VCM productivity for the $1 \mathrm{wt} \% \mathrm{Au} / \mathrm{C}$-AR catalyst under $\mathrm{HCl} / \mathrm{C}_{2} \mathrm{H}_{2} / \mathrm{Ar}$ reaction gas after different single-reactant gas treatments: (solid black circles) catalyst during the first induction period (productivity and white line data from step i, Figure 2), (open triangles) catalyst after $\mathrm{HCl} / \mathrm{Ar}$ treatment (productivity and white line data from step iii, Figure 2), and (half-filled diamonds) catalyst after $\mathrm{C}_{2} \mathrm{H}_{2} / \mathrm{Ar}$ treatment (productivity and white line data from step v, Figure 2).

Figure 2), as previously reported ${ }^{9}$ and shown in Figure 5, is strong with a Pearson's correlation coefficient value $r$ of -0.994 and observed gradient of $0.104( \pm 0.002)$. A similar correlation between the normalized white line height and VCM production for the reaction period after $\mathrm{HCl}$ treatment (step iii in Figure 2) is also evident, except that the gradient of the trend line changed to $0.057( \pm 0.007)$. A similar plot for the reaction period (step v) after $\mathrm{C}_{2} \mathrm{H}_{2}$ treatment gave a gradient of only $0.009( \pm 0.005)$, indicating that the relationship between productivity and normalized white line height was now almost invariant.

The simplest explanation for the loss of correlation after step $\mathrm{v}$ is that one or more additional spectator species, which contribute to the XANES in the region of the $\mathrm{Au}(\mathrm{I}) / \mathrm{Au}(\mathrm{III})$ white line, are present after treatment with $\mathrm{C}_{2} \mathrm{H}_{2} / \mathrm{Ar}$ and to a lesser extent after exposure to $\mathrm{HCl} / \mathrm{Ar}$. Such an explanation is supported by comparison of the XANES spectra of the catalyst at steady state for each reaction period (Figure 6), i.e., at the end of

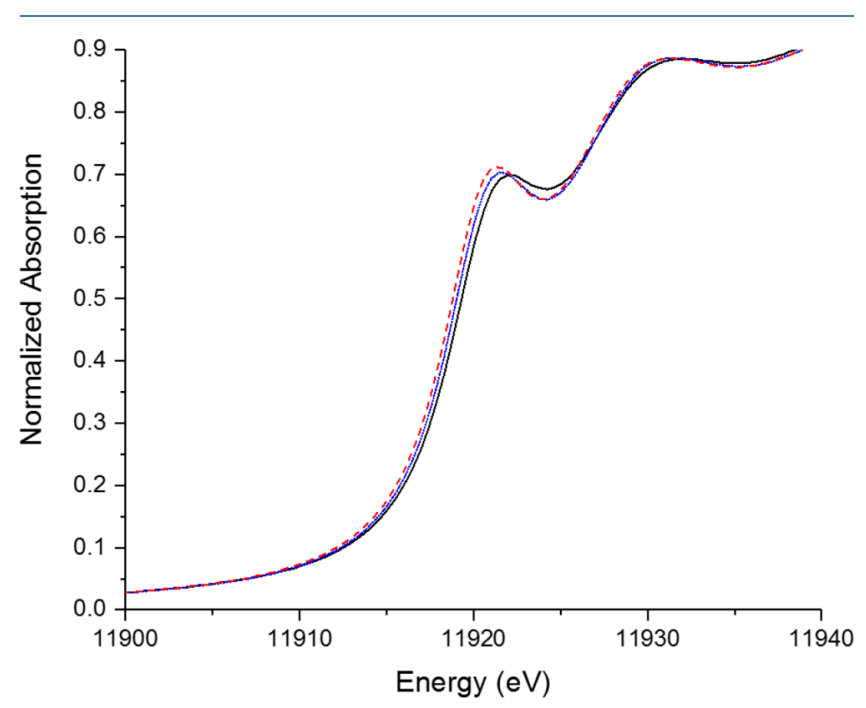

Figure 6. XANES spectra of the $1 \mathrm{wt} \% \mathrm{Au} / \mathrm{C}$-AR catalyst at steady acetylene hydrochlorination conditions after different sequential gas treatments: (red dotted line) first reaction (step i, Figure 2), (blue dotted line) second reaction (step iii, Figure 2, after $\mathrm{HCl} / \mathrm{Ar}$ treatment), and (black solid line) third reaction (step v Figure 2, after $\mathrm{C}_{2} \mathrm{H}_{2} / \mathrm{Ar}$ treatment).

the initial induction period (step i in Figure 2), at steady state after $\mathrm{HCl}$ treatment (step iii in Figure 2) and at the very end of the reaction after $\mathrm{C}_{2} \mathrm{H}_{2}$ (step $\mathrm{v}$ in Figure 2). A $1 \mathrm{eV}$ shift in the position of the white line, between the initial and the final steady-state spectra, indicates a notable change in Au speciation that is not apparent from white line height measurements alone.

Linear combination fitting (LCF) of these three spectra and those of the catalyst under $\mathrm{HCl} / \mathrm{Ar}$ and $\mathrm{C}_{2} \mathrm{H}_{2} / \mathrm{Ar}$ using $\mathrm{Au}(\mathrm{III}$ ), $\mathrm{Au}(\mathrm{I})$ and $\mathrm{Au}$ metal standards was performed to gain greater understanding of the changes in the XANES spectra and explain the loss in correlation between white line and VCM productivity in step $\mathrm{v}$ (Table 1). First, fitting of the catalyst under $\mathrm{C}_{2} \mathrm{H}_{2} / \mathrm{Ar}$

Table 1. Linear Combination Fitting of the 1 wt \% Au/C-AR Catalyst at the End of Each Sequence of Gas Switching ${ }^{a}$

\begin{tabular}{|c|c|c|c|}
\hline \multirow[b]{2}{*}{ reaction step ${ }^{b}$} & \multicolumn{3}{|c|}{ quantification (\%) } \\
\hline & $\mathrm{Au}(\mathrm{III})$ & $\mathrm{Au}(\mathrm{I})$ & $\mathrm{Au}(0)$ \\
\hline first reaction mixture (step i) & $28(4)$ & $71(3)$ & $0(3)$ \\
\hline $\mathrm{HCl} / \mathrm{Ar}$ (step ii) & $25(5)$ & $75(3)$ & $0(4)$ \\
\hline second reaction mixture (step iii) & $24(5)$ & $72(3)$ & $4(4)$ \\
\hline third reaction mixture (step iv) & $20(3)$ & $63(2)$ & $21(2)$ \\
\hline
\end{tabular}

${ }^{a}$ Percentage of $\mathrm{Au}$ associated with $\mathrm{Au}(\mathrm{I})$ chloride (standard $\left[\mathrm{AuCl}_{2}\right]^{-}$); $\mathrm{Au}(\mathrm{III})$ chloride (standard $\mathrm{KAuCl}_{4}$ ) and $\mathrm{Au}(0)$ metal (standard Au foil). ${ }^{b}$ Reaction sequence; step i $=\mathrm{HCl} / \mathrm{C}_{2} \mathrm{H}_{2} / \mathrm{Ar}$; step $\mathrm{ii}=\mathrm{HCl} / \mathrm{Ar}$; step $\mathrm{iii}=\mathrm{HCl} / \mathrm{C}_{2} \mathrm{H}_{2} / \mathrm{Ar}$; step iv $=\mathrm{C}_{2} \mathrm{H}_{2} / \mathrm{Ar}$, and step $\mathrm{v}=$ $\mathrm{HCl} / \mathrm{C}_{2} \mathrm{H}_{2} / \mathrm{Ar}$. ${ }^{c} \mathrm{NB}$. Analysis of step iv $\left(\mathrm{C}_{2} \mathrm{H}_{2} / \mathrm{Ar}\right)$ is excluded due to a poor fit.

was not successful in that no acceptable fit was found with the three standards chosen, further highlighting a strong interaction between $\mathrm{C}_{2} \mathrm{H}_{2}$ and the gold species present on the catalyst. 
The speciation of the of catalyst at the end of the first induction period under $\mathrm{HCl} / \mathrm{Ar}$ and during the second reaction period was comparable in terms of their $\mathrm{Au}(\mathrm{III})$ and $\mathrm{Au}(\mathrm{I})$ ratios; however, a small amount of metallic Au was possibly present from step ii. Given that the calculated $\mathrm{Au}(0)$ concentration was comparable to the estimated error, this result taken in isolation appears of limited value. However, clear evidence of metallic $\mathrm{Au}$ (ca. $21 \mathrm{wt} \%$ ) was found from LCF of the catalyst after $\mathrm{C}_{2} \mathrm{H}_{2} / \mathrm{Ar}$ treatment (step iv in Figure 2). As metallic Au is known to be catalytically inactive for acetylene hydrochlorination, this observation correlates well with the loss in activity seen after $\mathrm{C}_{2} \mathrm{H}_{2}$ treatment. Furthermore, given that $\mathrm{Au}(0)$ has a normalized absorption value of 0.6 at the energy of the $\mathrm{Au}$ (III) white line $(11920 \mathrm{eV})$ the presence of this species will reduce the white line intensity in a XANES spectrum of a sample containing $\mathrm{Au}(\mathrm{III}), \mathrm{Au}(\mathrm{I})$, and $\mathrm{Au}(0)$. In doing so the presence of $\mathrm{Au}(0)$ will disrupt the correlation between normalized white line height and VCM productivity. An example of how 0,25 , or $50 \mathrm{~mol} \%$ $\mathrm{Au}(0)$ effects the gradient of the white line height versus $\mathrm{Au}(\mathrm{III}): \mathrm{Au}(\mathrm{I})$ is shown in Figure $\mathrm{S} 1$ where increasing $\mathrm{Au}(0)$ content within the sample decreases the size of gradient of the plot.

Given that LCF using reference $\mathrm{KAuCl}_{4},\left[\mathrm{AuCl}_{2}\right]^{-}$, and $\mathrm{Au}$ foil materials cannot comprehensively model single-site $\mathrm{AuCl}_{x}$ species supported on a carbon surface, previous studies used the simpler analysis of white line height to give an average $\mathrm{Au}$ oxidation state. While white line height was satisfactory for analysis of the initial analysis (induction period and initial steady-state testing) of a two-component system ( $\mathrm{Au}(\mathrm{I})$ chloride and $\mathrm{Au}$ (III) chloride), LCF despite its flaws becomes required with this more complex multispeciation.

EXAFS Analysis of Au/C-AR Catalyst under Different Reactant Gases. While XANES analysis provides relevant information concerning Au speciation, the complex nature of the spectra requires additional EXAFS analysis to clarify interpretation. EXAFS of the catalyst at steady-state reactivity, before and after $\mathrm{HCl} / \mathrm{Ar}$ treatment and after $\mathrm{C}_{2} \mathrm{H}_{2}$ treatment, can provide further evidence of an increased contribution from metallic $\mathrm{Au}$ after sequential gas treatments. Figure 7 shows the magnitude

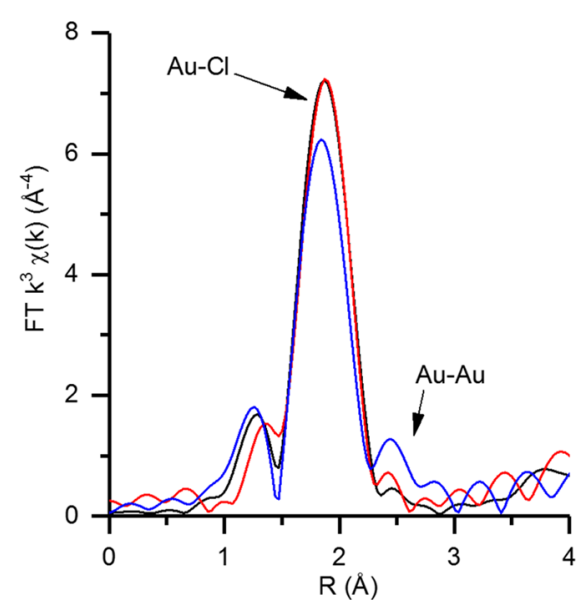

Figure 7. Magnitude of Fourier transform (FT) of extended X-ray absorption spectra $k^{3}$ weighted of 1 wt $\% \mathrm{Au} / \mathrm{C}-\mathrm{AR}$ catalyst under steady-state reaction conditions: (black line) FT of catalyst in step i, (red line) FT of catalyst in step iii, and (blue line) FT of catalyst in step iv.

of the Fourier transform data of the catalyst at the end of steps i, iii, and $\mathrm{v}$ in the reaction profile. The predominant feature in all samples is that of first shell $\mathrm{Au}-\mathrm{Cl}$ interactions with multiple
$\mathrm{Au}-\mathrm{Cl}$ scattering events beyond $3 \AA$. However, features associated with $\mathrm{Au}-\mathrm{Au}$ interactions between 2.5 and $3 \AA$ also become noticeable after treatment with $\mathrm{C}_{2} \mathrm{H}_{2}$ (although the FT magnitude is small), confirming the deduction form linear combination fitting of the XANES that metallic Au nanoparticles are generated during exposure to $\mathrm{C}_{2} \mathrm{H}_{2} / \mathrm{Ar}$.

EXAFS analysis (Figures S2 and S3, Table 2) can also provide further information on the nature of the Au speciation, especially while the catalyst was under an $\mathrm{C}_{2} \mathrm{H}_{2} / \mathrm{Ar}$-only environment. While the $\mathrm{Au} \mathrm{L}_{3}$ edge XANES of this species was clearly different to $\mathrm{Au}(\mathrm{I})$ or $\mathrm{Au}$ (III) chloride, EXAFS shows that $\mathrm{Au}-\mathrm{Cl}$ interactions are still present in the $\mathrm{C}_{2} \mathrm{H}_{2} / \mathrm{Ar}$-treated sample. The magnitude of this scattering in the Fourier transform data (Figure S3) is significantly lower under $\mathrm{C}_{2} \mathrm{H}_{2} / \mathrm{Ar}$ than the catalyst in the presence of both reactants $\left(\mathrm{C}_{2} \mathrm{H}_{2}+\mathrm{HCl} / \mathrm{Ar}\right)$. $\mathrm{No}$ additional features associated with $\mathrm{Au}-\mathrm{C}$ or $\mathrm{Au}-\mathrm{Au}$ interactions were observed in the $\mathrm{C}_{2} \mathrm{H}_{2}$-treated material, suggesting no significant $\mathrm{Au}-\mathrm{C}_{2} \mathrm{H}_{2}$ complex or $\mathrm{Au}(0)$ nanoparticle formation. Taking this into account, along with the dampened oscillations at higher wavenumbers in the $\chi$-space data (Figure S2), a model of $\mathrm{AuCl}_{x}$ with two $\mathrm{Au}-\mathrm{Cl}$ bond lengths that were partially out of phase was considered. The results of fitting two first-shell $\mathrm{Au}-\mathrm{Cl}$ lengths to the data are given in Table 2, which yields an $\mathrm{Au}-\mathrm{Cl}$ combined coordination number of $1.8(4)$ compared to that of 2.5(1) for the catalyst under normal steady-state conditions (fitted with a single $\mathrm{Au}-\mathrm{Cl}$ distance). It should be noted that no reasonable fitting of $2 \mathrm{Au}-\mathrm{Cl}$ paths was obtainable for any other sample investigated in steps ii, iii, and v. It was observed that a small component of the $\mathrm{Au}-\mathrm{Cl}$ interactions in the catalyst under $\mathrm{C}_{2} \mathrm{H}_{2} /$ Ar were notably shorter, at 2.110(57) $\AA$ compared to $2.273(6) \AA$ for the catalyst at steady-state conditions. Therefore, we conclude that the presence of excess acetylene results in the formation of some shortened $\mathrm{Au}-\mathrm{Cl}$ interactions but with no direct evidence of $\mathrm{Au}-\mathrm{C}_{2} \mathrm{H}_{2}$ bond formation. It should also be noted that evidence of multiple $\mathrm{Au}-\mathrm{Cl}$ distances was also previously observed during the induction period of the $\mathrm{Au} / \mathrm{C}-\mathrm{AR}$ catalyst in step $\mathrm{i}$ and illustrates that complex interactions between $\mathrm{AuCl}_{x}$ are present even under standard reaction conditions.'

EXAFS analysis (Table 2) of the catalyst at steady state under $\mathrm{HCl} / \mathrm{Ar}$ (step ii) and the second reaction mixture $\mathrm{HCl} / \mathrm{C}_{2} \mathrm{H}_{2}$ / $\mathrm{Ar}$ (step iii) showed little difference from that at steady state in the first reaction period. A slight reduction in $\mathrm{Au}-\mathrm{Cl} \mathrm{CN}$ number under $\mathrm{HCl} / \mathrm{Ar}$ was observed, in line with the moderate reduction in white line height also noted during this period. For the sample at steady state after the $\mathrm{C}_{2} \mathrm{H}_{2} / \mathrm{Ar}$ cycle (i.e., at the end of step v), a model with both $\mathrm{a} \mathrm{Au}-\mathrm{Cl}$ and $\mathrm{a} \mathrm{Au}-\mathrm{Au}$ interaction was found to provide good fitting parameters, further supporting the presence of metal in the deactivated catalyst.

XAFS sequential flow experiments highlighted several interesting observations that have not been observed in previous ex situ studies, namely, (i) the oxidation of the $\mathrm{Au}(\mathrm{I})-\mathrm{Cl}$ species appears far more facile in the presence of $\mathrm{C}_{2} \mathrm{H}_{2}$ and (ii) that $\mathrm{C}_{2} \mathrm{H}_{2}$ directly interacts with $\mathrm{AuCl}_{x}$ species, significantly altering the XANES spectra and changes $\mathrm{Au}-\mathrm{Cl}$ lengths when no $\mathrm{HCl}$ is present. The first point regarding $\mathrm{Au}(\mathrm{I})-\mathrm{Cl}$ oxidation can be further clarified by performing kinetic studies of the reaction to determine orders of reaction with respect to the reactant gases. If the apparent requirement for $\mathrm{Au}(\mathrm{I})-\mathrm{Cl}$ oxidation is the concerted addition of $\mathrm{HCl}$ and $\mathrm{C}_{2} \mathrm{H}_{2}$ (as suggested from XANES data) and if this step is rate limiting then the reaction should be first-order dependent with respect to each reactant. To prevent apparent zero-order responses, each reactant investigated was 
Table 2. In Situ EXAFS Fitting for Au $\mathrm{L}_{3}$-Edge Data of the 1 wt \% Au/C-AR Catalyst during the Sequential Gas Experiment

\begin{tabular}{|c|c|c|c|c|c|}
\hline reaction step ${ }^{a}$ & scattering path ${ }^{b}$ & coordination number & $R(\AA)$ & $E_{\mathrm{f}}(\mathrm{eV})$ & $R$ factor \\
\hline first reaction mixture (step i) & $\mathrm{Au}-\mathrm{Cl}$ & $2.5(1)$ & $2.27(1)$ & $1.2(9)$ & 0.0012 \\
\hline $\mathrm{HCl} / \mathrm{Ar}$ (step ii) & $\mathrm{Au}-\mathrm{Cl}$ & $2.4(1)$ & $2.27(1)$ & $3.3(0.99)$ & 0.007 \\
\hline second reaction mixture (step iii) & $\mathrm{Au}-\mathrm{Cl}$ & $2.5(1)$ & $2.27(1)$ & $2.55(66)$ & 0.004 \\
\hline \multirow[t]{2}{*}{$\mathrm{C}_{2} \mathrm{H}_{2} / \mathrm{Ar}$ (step iv) } & $\mathrm{Au}-\mathrm{Cl}(1)$ & $1.4(2)$ & $2.29(3)$ & $1.04(2.84)$ & 0.026 \\
\hline & $\mathrm{Au}-\mathrm{Cl}(2)$ & $0.5(2)$ & $2.11(6)$ & & \\
\hline \multirow[t]{2}{*}{ third reaction mixture (step v) } & $\mathrm{Au}-\mathrm{Cl}$ & $1.7(3)$ & $2.26(1)$ & $2.24(1.89)$ & 0.013 \\
\hline & $\mathrm{Au}-\mathrm{Au}$ & $1^{d}$ & $2.84(5)$ & & \\
\hline fixed parameters ${ }^{c}$ & $S_{\mathrm{o}}{ }^{2}=0.75 \mathrm{an}$ & $=0.0037$ & & & \\
\hline
\end{tabular}

${ }^{a}$ EXAFS data was taken under steady-state conditions during each sequential gas sequence step (i.e., when no change in three consecutive spectra was observed). ${ }^{b}$ Fitting with multiple $\mathrm{Au}-\mathrm{Cl}$ paths was attempted for all spectra. However, apart from $\mathrm{C}_{2} \mathrm{H}_{2} / \mathrm{Ar}$ (step iv), unrealistic fits such as high $R$ factors and/or negative amplitudes for second paths were obtained when using multiple paths. ${ }^{c}$ Debye-Waller and amplitude reduction factors were calculated from the fitting of a $\mathrm{KAuCl}_{4}$ standard with a fixed $\mathrm{CN}$ of 4 . ${ }^{d}$ Fittings of the $\mathrm{Au}-\mathrm{Cl}$ and $\mathrm{Au}-\mathrm{Au}$ for step v were performed fixing the $\mathrm{Au}-\mathrm{Au}$ coordination number to 1 .

studied over a range of highly dilute concentrations. The linear dependence of both $\mathrm{HCl}$ and $\mathrm{C}_{2} \mathrm{H}_{2}$ reaction rate, as shown in Figure 8, demonstrates first-order dependence with respect to each reactant and second-order reaction kinetics overall. The combined evidence from in situ XANES experiments and the measured first-order dependence for each reactant provides strong evidence for a concerted $\mathrm{HCl}$ and $\mathrm{C}_{2} \mathrm{H}_{2}$ addition to the $\mathrm{Au}(\mathrm{I})-\mathrm{Cl}$ active site.

Inelastic Neutron Scattering (INS): Effect of $\mathrm{C}_{2} \mathrm{H}_{2}$ on $\mathrm{Au}$ Complex Speciation. Vibrational spectroscopy provides a viable method to clarify the effect of $\mathrm{C}_{2} \mathrm{H}_{2}$ on $\mathrm{Au}$ complex speciation, as seen during the $\mathrm{C}_{2} \mathrm{H}_{2} / \mathrm{Ar}$ treatment in step iv of the reaction sequence. As the carbon support in the catalyst would be highly absorbent of infrared radiation, we attempted inelastic neutron scattering (INS) spectroscopy. While INS is suited to observing hydrogen speciation in the $\mathrm{C}_{2} \mathrm{H}_{2} /$ Ar-treated sample and therefore the nature of the Au complex, it suffers from low signal-to-noise (due to the required interaction of the neutron with the small nucleus of the absorber). To mitigate this problem a more heavily loaded $2 \mathrm{wt} \% \mathrm{Au} / \mathrm{C}-\mathrm{AR}$ sample was prepared to increase the concentration of Au species available for interaction with acetylene in the sample. XAFS, XRD, and STEM analysis of the $2 \mathrm{wt} \% \mathrm{Au} / \mathrm{C}-\mathrm{AR}$ material demonstrated that this more highly loaded catalyst was still comprised of single-site cationic Au species with a negligible concentration of metallic gold nanoparticles (Figure S4, Figure 9a-d).

The 2 wt \% Au/C-AR catalyst was sequentially treated under helium and a dilute acetylene gas mixture $\left(5 \% \mathrm{C}_{2} \mathrm{H}_{2} / \mathrm{He}\right.$ or concentrated acetylene (100\%) in a reaction cell for ca. $30 \mathrm{~min}$ at $200{ }^{\circ} \mathrm{C}$. Between each step the sample was cooled (to minimize Debye-Waller contributions) and the cell flushed with He prior to acquisition of the INS spectrum. The resulting spectrum provides detail of acetylene species while the catalyst is exposed to an excess of acetylene under reaction conditions. The spectra of $2 \mathrm{wt} \% \mathrm{Au} / \mathrm{C}-\mathrm{AR}$ sample prior to acetylene treatment (used as a background spectrum), 2 wt \% Au/C-AR after treatment in 5\% acetylene, and $100 \%$ acetylene are shown in Figure S5. Reaction with the $\mathrm{C}_{2} \mathrm{H}_{2}(5 \%) / \mathrm{He}$ mixture resulted in no observable changes in the spectrum, whereas in contrast reaction with $100 \% \mathrm{C}_{2} \mathrm{H}_{2}$ results in bands at 2990,1295, 961, 700, and 640 (and possibly 400) $\mathrm{cm}^{-1}$. The difference spectra $\mathrm{C}_{2} \mathrm{H}_{2}$ (5\%) dosed minus the background, $\mathrm{C}_{2} \mathrm{H}_{2} 100 \%$ dosed minus the background, and $\mathrm{C}_{2} \mathrm{H}_{2}$ (100\%) dosed minus $\mathrm{C}_{2} \mathrm{H}_{2}$ (5\%) dosed are shown in Figure 10.

INS spectra of metal-acetylide, silver, ${ }^{25,26}$ silver/copper, ${ }^{27}$ copper, ${ }^{28,29}$ and gold $^{30-34}$ complexes have been widely reported. The bands seen in the difference spectra of $(100 \%)$ $\mathrm{C}_{2} \mathrm{H}_{2}$ - background were compared to that of $\mathrm{Au}-\mathrm{C} \equiv \mathrm{C}-\mathrm{H}$
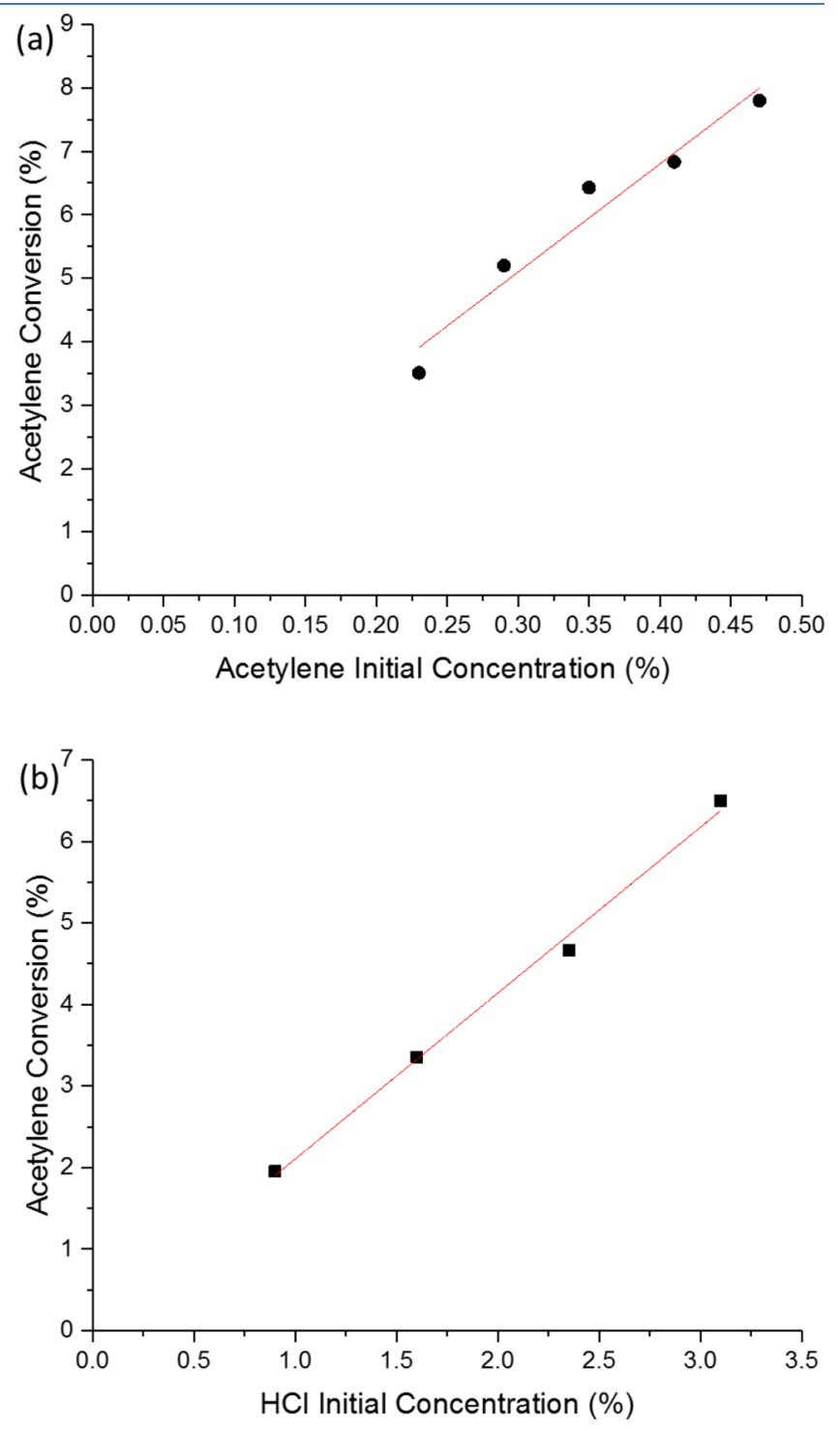

Figure 8. Determination of orders of reaction with respect to the component reactant gases. Linear dependence was found for both (a) $\mathrm{C}_{2} \mathrm{H}_{2}$ concentration and (b) $\mathrm{HCl}$ concentration on reaction rate. Reaction conditions: Catalyst ( $0.045 \mathrm{~g}), 200{ }^{\circ} \mathrm{C}$, ambient pressure, various concentrations of gases ( $\mathrm{HCl}$ in excess) balanced with $\mathrm{Ar}$ at a fixed flow of $50 \mathrm{~mL} \mathrm{~min}-1$.

modeled as an isolated molecule, an adsorbed molecule on a single carbon atom of a graphene sheet (to model the carbon 

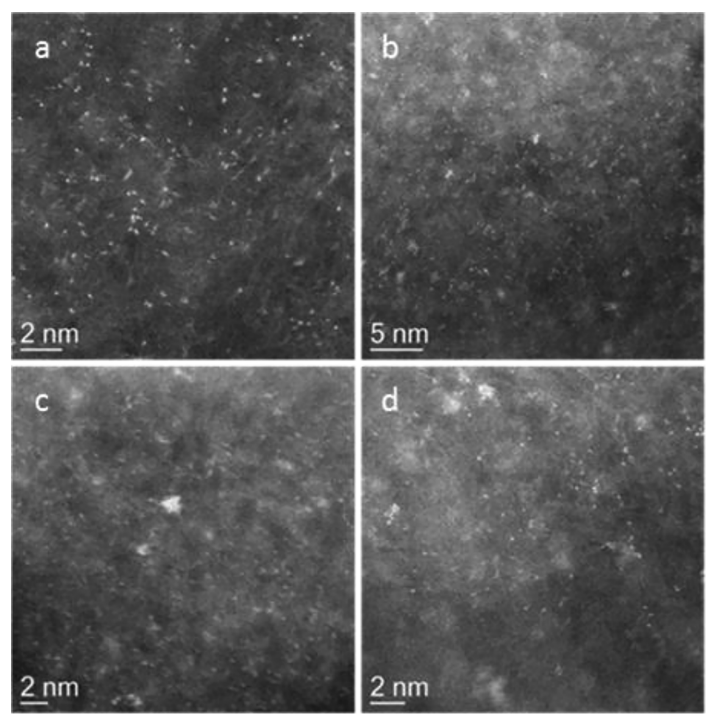

Figure 9. HAADF-STEM images of the 2 wt \% Au/C-AR catalyst before use. In the unused sample atomically dispersed Au could be easily seen ( $a$ and $b)$, while a small number of subnm Au clusters were also present ( $c$ and $d)$.

support), and an adsorbed molecule above the center of a graphene hexagon (see Figure S6). All three models exhibit $\equiv$ $\mathrm{C}-\mathrm{H}$ stretches at $\sim 3300 \mathrm{~cm}^{-1}$, a $\mathrm{C} \equiv \mathrm{C}$ stretch at $\sim 2000 \mathrm{~cm}^{-1}$, a $\mathrm{C} \equiv \mathrm{C}-\mathrm{H}$ bending mode at $\sim 600 \mathrm{~cm}^{-1}$, and an $\mathrm{Au}-\mathrm{C}$ stretch at $\sim 250 \mathrm{~cm}^{-1}$. As shown in Figure 11, none of the calculated spectra match the observed spectrum of the catalyst after acetylene treatment. Given the possibility of $\mathrm{Au}(0)$ formation after acetylene treatment as suggested from LCF of XANES and EXAFS analysis, models for acetylene bound to Au nanoparticles were also considered. However, in common to the metalacetylide spectra no correlation could be found between the models of acetylene bound to an $\mathrm{Au}_{4}$ tetrahedron (representing a small $\mathrm{Au}$ cluster) and the experimental spectrum.

An alternative assignment to the observed bands on the $2 \mathrm{wt} \%$ $\mathrm{Au} / \mathrm{C}$-AR catalyst after $\mathrm{C}_{2} \mathrm{H}_{2}$ treatment is that of oligomerized acetylene species. Previously, carbon fibers have been observed by TEM analysis to have grown on spent Au/C-AR catalysts after 24 days time-online. ${ }^{6}$ The INS spectrum of polyacetylene shown in Figure 12 exhibits bands at similar energies to those seen on the 2 wt \% Au/C-AR catalyst after $\mathrm{C}_{2} \mathrm{H}_{2}$ treatment. ${ }^{35}$ However, there are several modes absent in the 2 wt \% Au/C-AR catalyst after $\mathrm{C}_{2} \mathrm{H}_{2}$ treatment, as compared to polyacetylene. Potentially these absent modes are associated with shorter oligomeric species on the catalyst surface. To test this possibility, all-trans-1,3,5,7-octatetraene (inset in Figure 12) was used as a model for a short-chain acetylene oligomer. Figure 12 compares the experimental and calculated spectra and indicates good agreement, particularly regarding the $1295 \mathrm{~cm}^{-1}$ mode that is clearly present.

The used catalyst after the INS experiment was then analyzed ex situ by XAFS and STEM (Figure S7). The XANES spectrum recorded is almost identical to the one obtained for the $1 \% \mathrm{Au} /$ $\mathrm{C}$-AR catalyst during step iv of the sequential flow experiment $\left(\mathrm{C}_{2} \mathrm{H}_{2} / \mathrm{Ar}\right)$. Moreover, also in this case, the $\mathrm{Au}-\mathrm{Cl}$ intensity in the EXAFS FT decreased, compared to the spectrum of the freshly prepared catalyst shown in Figure S7, while the STEMHAADF images (Figure 13) show that the gold is still predominantly dispersed as atomic on the carbon support.

The INS data shows for the first time the presence of oligomeric acetylene species, while the Au XANES shows a
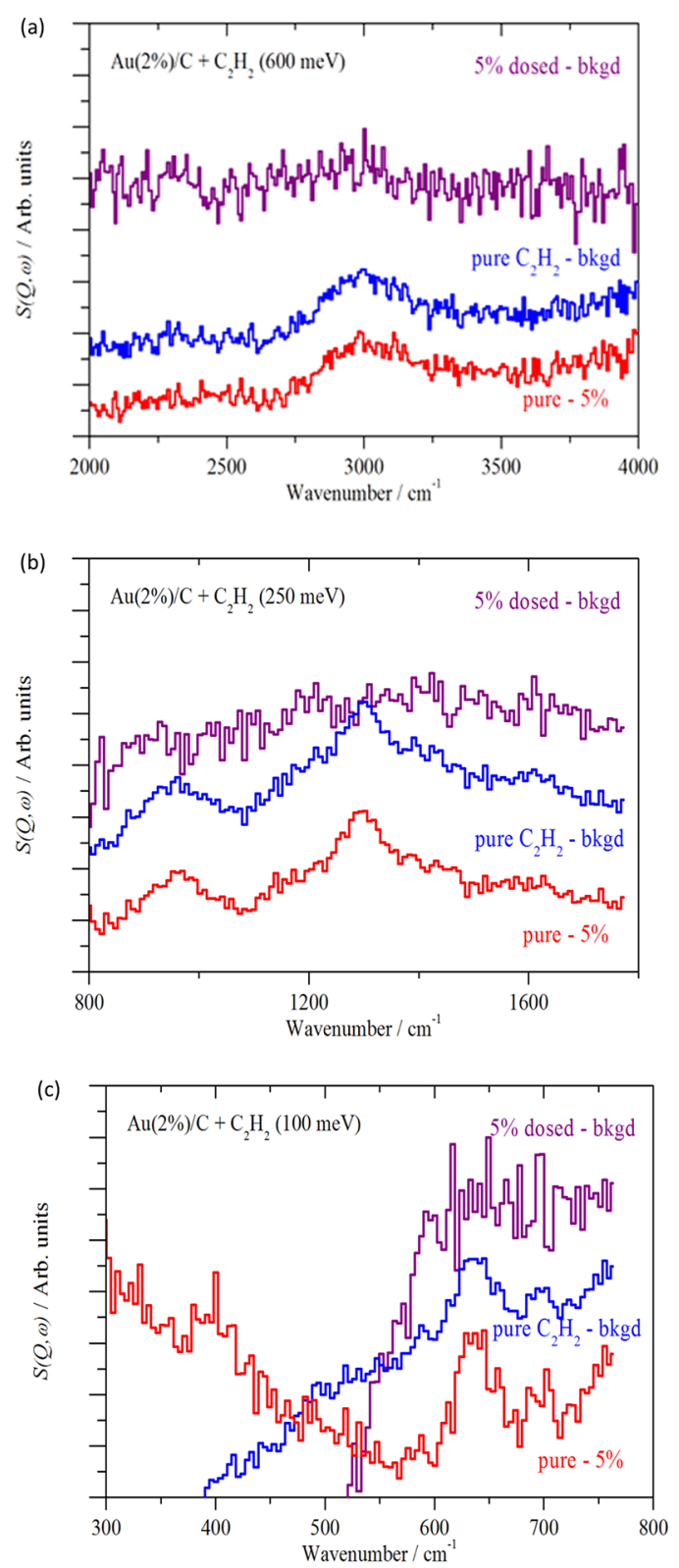

Figure 10. INS difference spectra obtained from the 2 wt $\% \mathrm{Au} / \mathrm{C}-\mathrm{AR}$ catalyst in (a) the $\mathrm{C}-\mathrm{H} / \mathrm{O}-\mathrm{H}$ stretch region, (b) the $\mathrm{C}-\mathrm{H}$ in-plane bend and $\mathrm{C}-\mathrm{C}$ stretch region, and $(\mathrm{c})$ the $\mathrm{C}-\mathrm{H}$ out-of-plane bend region.

clearly altered $\mathrm{Au}$ species after $\mathrm{C}_{2} \mathrm{H}_{2}$ treatment. Unfortunately, there is no clear evidence that these two species are connected, as no evidence of $\mathrm{Au}$-acetylene bonding was found from either XANES or INS. However, we provide clear evidence of the significant surface acetylene species that become evident on exposure to a $\mathrm{C}_{2} \mathrm{H}_{2}$ excess in a reactant gas mixture, which is known to be detrimental to catalytic activity.

In Situ Deactivation of $2 \% \mathrm{Au} / \mathrm{C}-\mathrm{AR}$ during the Acetylene Hydrochlorination Reaction. Catalyst deactivation, associated with $\mathrm{Au}(0)$ formation and a loss of the correlation between white line height and VCM productivity, was observed in the $1 \% \mathrm{Au} / \mathrm{C}$-AR catalyst over multiple different sequential gas experiments. To clarify if a similar deactivation process occurs, without various sequential gas treatments, a continuous extended time-online experiment with a constant gas composition coupled with in situ XAFS monitoring could in 

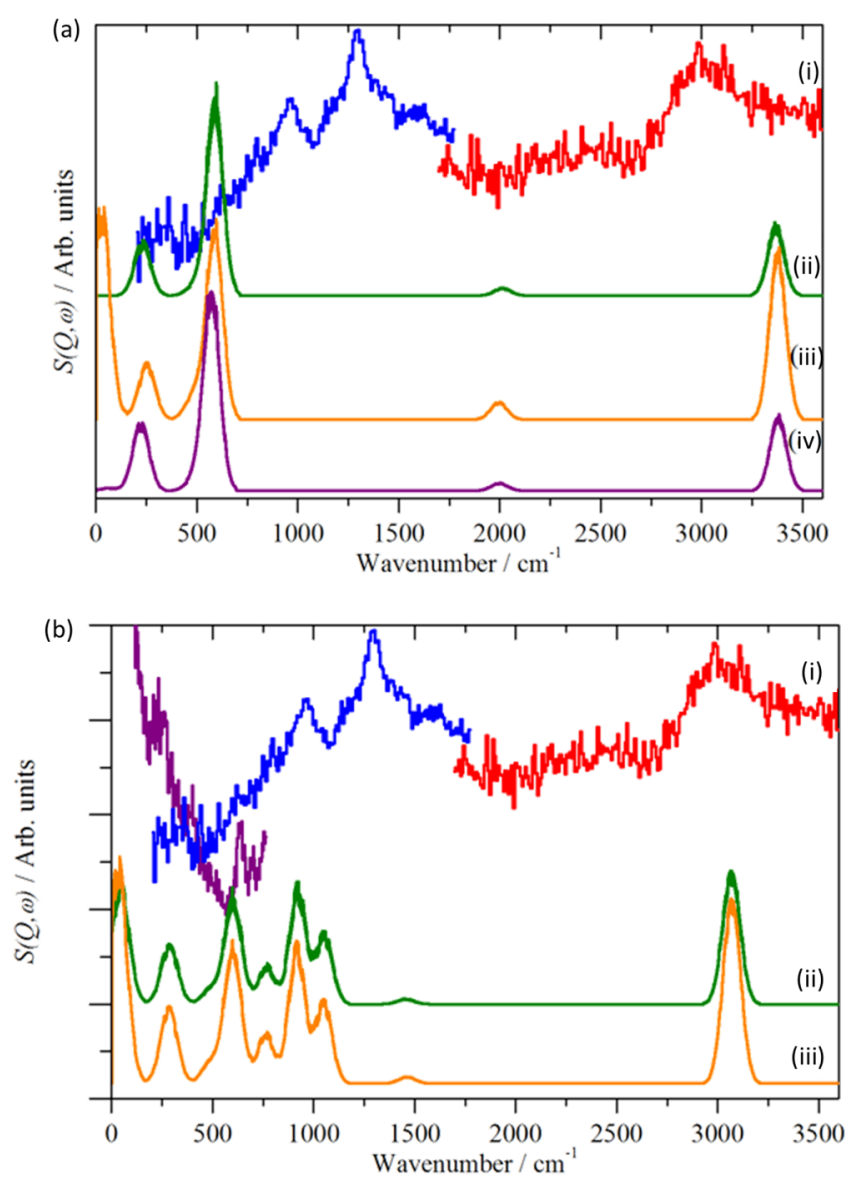

Figure 11. (a) Comparison of INS spectrum of (i) $\left(\mathrm{C}_{2} \mathrm{H}_{2}\right.$ (100\%) dosed $-\mathrm{C}_{2} \mathrm{H}_{2}(5 \%)$ dosed) with those calculated for gold acetylide as (ii) an isolated molecule, (iii) a molecule adsorbed in the on-top site on graphene, and (iv) a molecule adsorbed in the 6-fold site on graphene. (b) Comparison of INS spectrum of (i) $\left(\mathrm{C}_{2} \mathrm{H}_{2}(100 \%)\right.$ dosed $-\mathrm{C}_{2} \mathrm{H}_{2}$ (5\%) dosed) with those calculated for $\mathrm{Au}_{4} \mathrm{C}_{2} \mathrm{H}_{2}$ as (ii) an isolated molecule and (iii) a molecule adsorbed on graphene.

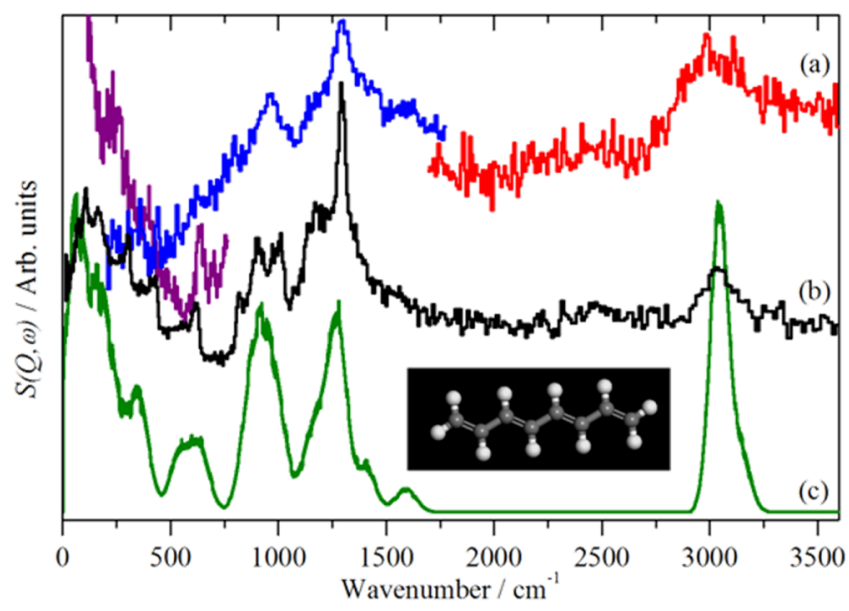

Figure 12. Comparison of INS spectrum of $(\mathrm{a})\left(\mathrm{C}_{2} \mathrm{H}_{2}(100 \%)\right.$ dosed $\mathrm{C}_{2} \mathrm{H}_{2}(5 \%)$ dosed) with (b) polyacetylene ${ }^{36}$ recorded on a TOSCA-like INS spectrometer and (c) that calculated for all-trans-1,3,5,7-octatetraene. (Inset) Idealized structure of all-trans-1,3,5,7-octatetraene.

principle be performed. Such an experiment is not easily carried out with a $1 \mathrm{wt} \% \mathrm{Au} / \mathrm{C}-\mathrm{AR}$ catalyst as the deactivation period is too long to be monitored over a single synchrotron beam time experiment. However, the 2 wt \% Au/C-AR catalyst used for

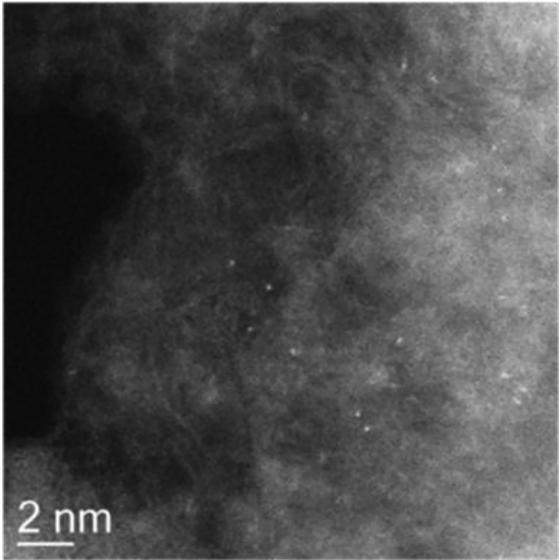

Figure 13. HAADF-STEM images of the $2 \mathrm{wt} \% \mathrm{Au} / \mathrm{C}$-AR catalyst after use showing atomically dispersed $\mathrm{Au}$ entities.

INS studies, with its comparable initial single-site dispersion of $\mathrm{AuCl}_{x}$ species, would be expected to undergo a more rapid deactivation associated with $\mathrm{Au}(0)$ particle formation, due to the higher concentration of $\mathrm{Au}$ available for agglomeration.

The structural behavior of the 2 wt \% Au/C-AR catalyst was found to be initially comparable with that of the $1 \mathrm{wt} \% \mathrm{Au} /$ $\mathrm{C}$-AR material with a decrease in normalized white line height upon heating under Ar from 1.07 at $25{ }^{\circ} \mathrm{C}$ to 0.68 at $200{ }^{\circ} \mathrm{C}$ (Figure S8). Linear combination fitting of the 2 wt \% Au/C-AR catalyst at $200{ }^{\circ} \mathrm{C}$ confirmed the absence of $\mathrm{Au}(0)$ before introduction of the reaction mixture. As the reaction mixture was introduced the normalized white line increased from 0.68 to 0.85 (Figure 14a), as observed in the $1 \mathrm{wt} \% \mathrm{Au} / \mathrm{C}-\mathrm{AR}$ catalyst. The white line height then began to decrease over a $20 \mathrm{~min}$ period, commensurate with an increase in VCM productivity, as seen for the induction period of the $1 \mathrm{wt} \%$ catalyst. From this point in the reaction the evolution of VCM productivity and association with normalized white line height, diverges for the 2 wt \% Au/C-AR catalyst. After ca. 40 min reaction, the higher loading catalyst undergoes a gradual and prolonged loss in activity, with VCM productivity dropping by $40 \%$ between 40 and $200 \mathrm{~min}$ time-online. As predicted from the sequential gas experiments, on the $1 \mathrm{wt} \% \mathrm{Au} / \mathrm{C}$-AR catalyst, the observed normalized white line height remained relatively consistent over the deactivation period. As the reaction proceeded for another $150 \mathrm{~min}$, EXAFS and LCF showed that the catalyst developed considerable amounts of metallic Au (ca. 22.5\%) in addition to $\mathrm{AuCl}_{x}$ species (Figures 14a, 14b, and 15).

HAADF-STEM images of the used 2 wt \% Au/C-AR catalyst confirmed the presence of single-site species in addition to larger particles of $\mathrm{Au}$ (Figures $16 \mathrm{a}-\mathrm{c}$ ) in the $20-100 \mathrm{~nm}$ size range. This observation suggests that once the $\mathrm{AuCl}_{x}$ single-site species reduced to $\mathrm{Au}(0)$, sintering occurred very efficiently under reaction conditions. Counting the numbers of $\mathrm{Au}$ atoms over certain areas of the carbon support from several HAADFSTEM images gave estimated $\mathrm{Au}$ atom densities of 0.470 and 0.154 atoms $/ \mathrm{nm}^{2}$ for the unused and used 2 wt \% Au/C-AR catalysts, respectively (see Table 3 ). This suggests that $\sim 2 / 3$ of atomic $\mathrm{Au}$ transformed into large $\mathrm{Au}$ particles during the reaction, leading to a significantly decreased Au dispersion.

\section{CONCLUSIONS}

Single-site $\mathrm{Au} / \mathrm{C}$ catalysts, prepared by impregnation and using aqua regia $\mathrm{Au}$ solution, were studied by XAFS and INS under 

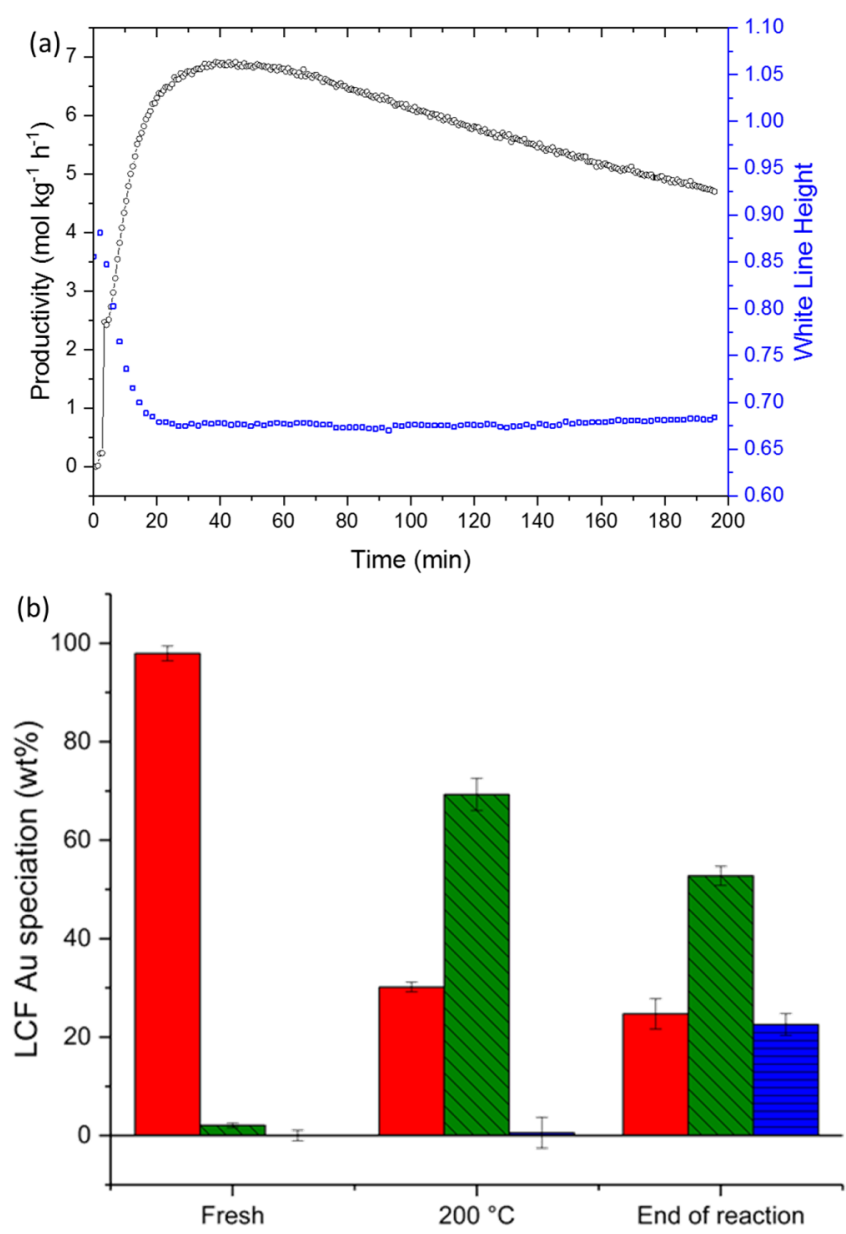

Figure 14. (a) VCM productivity of the 2 wt $\%$ Au/C-AR catalyst during the first $200 \mathrm{~min}$ of reaction combined with in situ $\mathrm{Au} \mathrm{L}_{3}$-edge XANES analysis: (open black circles) VCM production as a function of time online. Simultaneously acquired normalized white line data (blue open squares). (b) Linear combination fitting for the fresh 2 wt \%Au/ $\mathrm{C}-\mathrm{AR}$ catalyst as prepared at room temperature, once it had reached $200{ }^{\circ} \mathrm{C}$ under $\mathrm{Ar}$ and at the end of the reaction (after $350 \mathrm{~min}$ ). Percentage of Au associated with $\mathrm{Au}(\mathrm{I})$ chloride (standard $\left.\left[\mathrm{AuCl}_{2}\right]^{-}\right)$is shown in red, $\mathrm{Au}(\mathrm{III})$ chloride (standard $\mathrm{KAuCl}_{4}$ ) is shown in green, and $\mathrm{Au}(0)$ metal (standard $\mathrm{Au}$ foil) is shown in blue.

various reactant gas compositions to gain a greater understanding of the reaction mechanism and mode of catalyst deactivation. Sequential gas experiments showed that $\mathrm{HCl}$ in the absence of $\mathrm{C}_{2} \mathrm{H}_{2}$ cannot reoxidize $\mathrm{Au}(\mathrm{I})$-chloride species under the reaction conditions studied and that $\mathrm{HCl}$ addition requires concerted addition with $\mathrm{C}_{2} \mathrm{H}_{2}$. Exposure of the $\mathrm{Au} / \mathrm{C}$ catalyst to $\mathrm{C}_{2} \mathrm{H}_{2}$ (in the absence of $\mathrm{HCl}$ ) resulted in a XANES spectrum that did not resemble $\mathrm{Au}(\mathrm{III})$ chloride, $\mathrm{Au}(\mathrm{I})$ chloride, or $\mathrm{Au}(0)$, while EXAFS analysis suggested that $\mathrm{AuCl}_{x}$ species were retained but with distorted $\mathrm{Au}-\mathrm{Cl}$ distances. INS studies of a $\mathrm{Au} / \mathrm{C}$ catalyst exposed to $\mathrm{C}_{2} \mathrm{H}_{2}$ showed that oligomeric acetylene species formed on the catalyst surface, which could act as potential precursors to carbon fiber formation and thus become a significant deactivation process.

Catalyst deactivation, after $\mathrm{C}_{2} \mathrm{H}_{2}$ treatment or prolonged time-online studies with higher Au loadings, was found to be associated with the formation of metallic $\mathrm{Au}$ particles. The presence of $\mathrm{Au}(0)$ significantly affected the strong correlation between normalized white line height and VCM productivity seen in a completely single-site catalyst (i.e., in the absence of

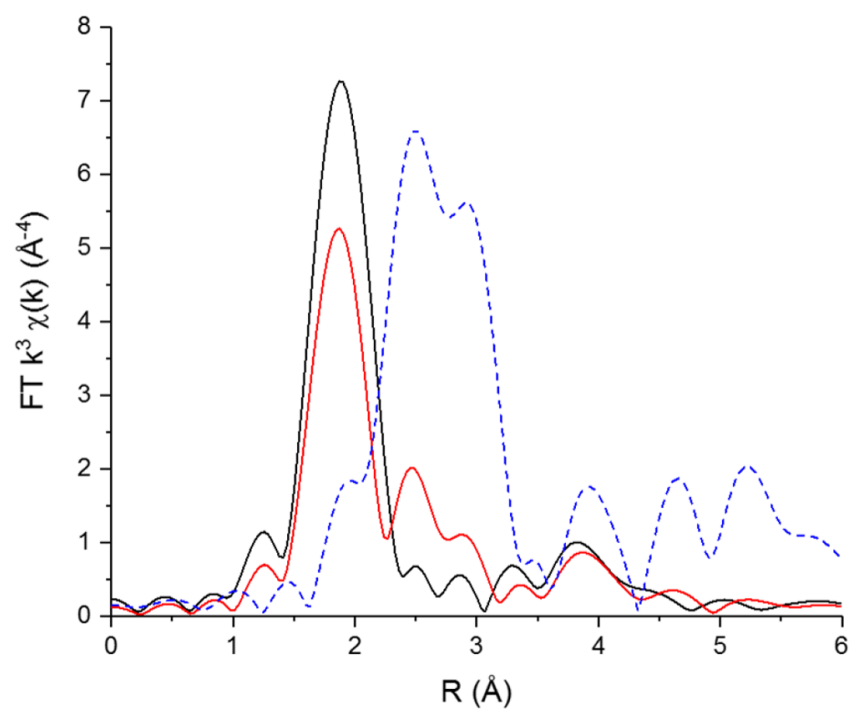

Figure 15. Magnitude of Fourier transform (FT) of extended X-ray absorption spectra $k^{3}$ weighted from the $2 \mathrm{wt} \% \mathrm{Au} / \mathrm{C}$-AR catalyst in the "as-prepared state" and "used state" (after $350 \mathrm{~min}$ of reaction): (black line) FT of the fresh catalyst, (red line) FT of the catalyst after $350 \mathrm{~min}$ of reaction, and (blue line) FT of the reference material gold foil.

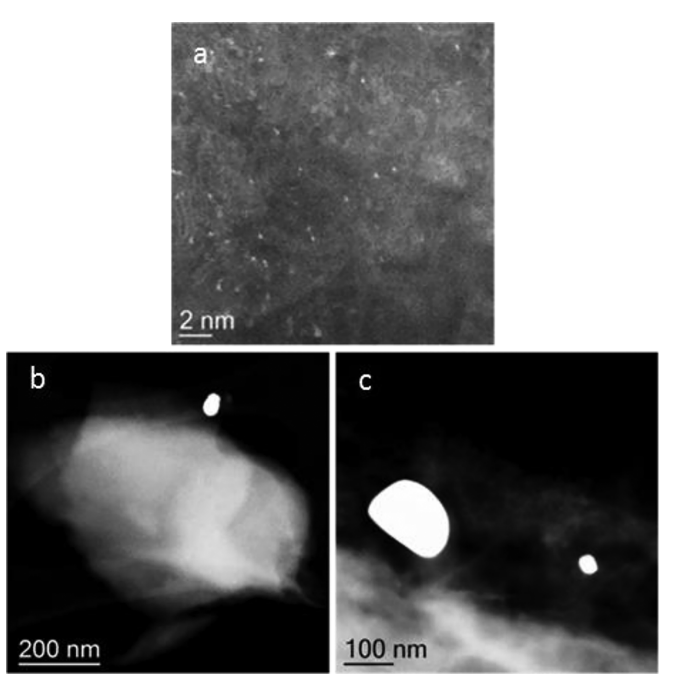

Figure 16. HAADF-STEM images of the $2 \mathrm{wt} \% \mathrm{Au} / \mathrm{C}$-AR catalyst after use. In the material after use a mixture of (a) atomically dispersed $\mathrm{Au}$ entities and $(b, c)$ larger Au particles were observed.

$\mathrm{Au}(0)$ particles). Care must be taken to consider other spectator species that may be present from catalyst preparation or evolve during the reaction. Simple descriptors of catalyst structure, such as white line height, while useful, must be carefully used in systems of increased complexity.

\section{EXPERIMENTAL SECTION}

Catalyst Preparation. One and 2 wt \% gold supported on activated carbon catalysts were prepared by wet impregnation of the $\mathrm{HAuCl}_{4}$ precursor dissolved in aqua regia (denoted, respectively, as 1 wt \% Au/C-AR and 2 wt \% Au/C-AR materials). Activated carbon (Norit ROX 0.8) was initially ground to obtain a $100-140$ mesh powder. The gold precursor, $\mathrm{HAuCl}_{4}$. $x \mathrm{H}_{2} \mathrm{O}$ (Alfa Aesar, 99.9\% (metals basis), Au 49\%), was dissolved in aqua regia (3 parts by volume $\mathrm{HCl}$ [(Fisher, 32 wt \%)]:1 part by volume $\mathrm{HNO}_{3}[($ Fisher, $\left.70 \mathrm{wt} \%)]\right)$. The gold precursor 
Table 3. Atom Density Measurements from Sets of STEM Images of the 2 wt \% Au/C-AR Catalyst before and after Acetylene Hydrochlorination Reaction

\begin{tabular}{|c|c|c|c|c|c|c|c|}
\hline \multicolumn{4}{|c|}{2 wt $\% \mathrm{Au} / \mathrm{C}-\mathrm{AR}$ fresh } & \multicolumn{4}{|c|}{$2 \mathrm{wt} \% \mathrm{Au} / \mathrm{C}-\mathrm{AR}$ post reaction } \\
\hline image & atoms counted & area $\left(\mathrm{nm}^{2}\right)$ & area density (atoms $\mathrm{nm}^{-2}$ ) & image & atoms counted & area $\left(\mathrm{nm}^{2}\right)$ & area density (atoms $\mathrm{nm}^{-2}$ ) \\
\hline 1 & 146 & 338.26 & 0.432 & 7 & 84 & 247.46 & 0.339 \\
\hline 2 & 105 & 314.24 & 0.334 & 8 & 102 & 821.91 & 0.124 \\
\hline 3 & 130 & 378.42 & 0.344 & 9 & 52 & 312.86 & 0.166 \\
\hline 4 & 41 & 142.54 & 0.288 & 10 & 28 & 348.76 & 0.080 \\
\hline 5 & 104 & 94.60 & 1.099 & 11 & 46 & 294.32 & 0.156 \\
\hline 6 & 193 & 262.80 & 0.734 & & & & \\
\hline total & 719 & 1530.86 & 0.470 & total & 312 & 2025.32 & 0.154 \\
\hline
\end{tabular}

solution was then added dropwise with stirring to the activated carbon. Stirring was continued at ambient temperature until $\mathrm{NO}_{x}$ production had subsided. The product was then dried for $16 \mathrm{~h}$ at $140{ }^{\circ} \mathrm{C}$ under an inert flow of nitrogen.

In Situ Powder X-ray Diffraction (XRD). Powder XRD data were acquired using an X'Pert Pro PAN Analytical powder diffractometer employing a $\mathrm{Cu} \mathrm{K} \alpha$ radiation source operating at $40 \mathrm{keV}$ and $40 \mathrm{~mA}$. Analyses of the spectra were carried out using X'Pert High Score Plus software. The mean crystallite size of the metallic gold nanoparticles was determined using the Scherrer equation assuming a spherical particle shape and a $K$ factor of 0.9 on the reflection arising from the $\{111\} \mathrm{Au}$ planes $\left(\right.$ at $\left.2 \theta=38^{\circ}\right)$.

In Situ X-ray Absorption Fine Structure (XAFS). XAFS spectra were recorded in transmission mode at the $\mathrm{Au} \mathrm{L}_{3}$ absorption edge, at the B18 beamline of the Diamond Light Source, at Harwell, UK. The measurements were performed using a QEXAFS setup with a fast-scanning Si (111) double-crystal monochromator. For the in situ measurements, the time resolution of the data acquisition was 20 s per spectrum.

$\mathrm{X}$-ray absorption near-edge structure (XANES) analysis was mainly focused on understanding the details of the white line feature detectable at an absorption energy of $\sim 11920 \mathrm{eV}$, which corresponds to the $\mathrm{Au} 2 \mathrm{p}_{3 / 2} \rightarrow 5 \mathrm{~d}$ primary transition. Three different $\mathrm{Au}$ standards were used to perform a linear combination fitting (LCF) analysis of the $\mathrm{Au} \mathrm{L}_{3}$-edge XANES, namely, $\mathrm{KAuCl}_{4} /\left[\mathrm{AuCl}_{4}\right]^{-}$for $\mathrm{Au}(\mathrm{III}),\left[\mathrm{AuCl}_{2}\right]^{-}$for $\mathrm{Au}(\mathrm{I})$, and a bulk $\mathrm{Au}$-foil for $\mathrm{Au}(0)$. The normalized white line intensity values observed for the $\left[\mathrm{AuCl}_{4}\right]^{-}$and $\left[\mathrm{AuCl}_{2}\right]^{-}$standards were 1.1 and 0.6 , respectively.

Analysis of the extended X-ray absorption fine structure (EXAFS) data was performed using IFEFFIT with the Demeter software package (Athena and Artemis). ${ }^{36,37}$ First-shell Au paths were fitted at all $k$-weighted $\chi$ data using a $k$ space window of $3-11$ and an $R$ window of 1.25-2.60. The Debye-Waller $\left(2 \sigma^{2}\right)$ and the amplitude reduction $\left(S_{\mathrm{o}}{ }^{2}\right)$ factors were fixed during fitting of data at $0.0037 \AA^{2}$ and 0.75 , respectively. These values were determined from fitting of $\mathrm{KAuCl}_{4}$ at a known temperature and with a fixed coordination number $(\mathrm{CN})$ of $4 .^{9}$

Inelastic Neutron Scattering (INS). For INS analysis, the required amount of $2 \% \mathrm{Au} / \mathrm{C}-\mathrm{AR}$ catalyst was loaded into a Conflat-sealed stainless steel cell and then dried at $200{ }^{\circ} \mathrm{C}$ under vacuum. INS spectra of the dried catalyst were recorded with the MERLIN spectrometer at the ISIS Facility ${ }^{38}$ using incident energies of 600,250 , and $100 \mathrm{meV}$ to observe the $\mathrm{C}-\mathrm{H} / \mathrm{O}-\mathrm{H}$ stretch, in-plane $\mathrm{C}-\mathrm{C}$ stretches/C-H bends, and the out-ofplane deformations, respectively. These spectra were used as backgrounds for all subsequent spectra. The catalyst was then dosed with $\mathrm{C}_{2} \mathrm{H}_{2}(5 \%) / \mathrm{He}$ at $200{ }^{\circ} \mathrm{C}$. After measurement of the spectra, the catalyst was then dosed with $100 \% \mathrm{C}_{2} \mathrm{H}_{2}$ at $200{ }^{\circ} \mathrm{C}$ and the spectra measured. All of the spectra were recorded at $<20 \mathrm{~K}$ to minimize the Debye-Waller factor.

Computational studies of model systems were carried out using the plane-wave pseudopotential code CASTEP. Isolated molecule calculations were carried out with the molecule in the center of either a $10 \times 10 \times 10 \AA$ or a $15 \times 15 \times 15 \AA$ box. To investigate the effect of the surface, the same molecules were placed above a single graphene layer with a $10 \AA$ vacuum gap. The Perdew-Burke-Ernzerhof (PBE) functional was used; the plane-wave cutoff was $750-1000 \mathrm{eV}$. For the isolated molecules only the $\Gamma$ point was included; for the surface calculations a Monkhorst-Pack grid of $8 \times 8 \times 1$ (12k points) or $9 \times 9 \times 1$ (20k points) was used. The calculations were converged to better than $\pm 0.003 \mathrm{eV}^{-1}$. After geometry optimization, the vibrational modes were calculated using density functional perturbation theory as implemented in CASTEP. ${ }^{39}$ The CASTEP output includes the vibrational transition energies and the atomic displacements of the atoms in each mode. The latter enables visualization of the modes using Materials Studio and is also the input to the program AbINS ${ }^{40}$ that creates simulated INS spectra. AbINS can generate the full 2D $S(Q, \omega)$ map for comparison with the output of direct geometry INS spectrometers such as MERLIN. Cuts through the data assume constant resolution and have the correct $Q$ dependence and treatment of the Debye-Waller factor so that comparison with experimental data is both straightforward and reliable.

Scanning Transmission Electron Microscopy (STEM). Materials for examination by STEM were dry dispersed onto a holey carbon TEM grid. These supported fragments were examined using BF- and HAADF-STEM imaging mode in an aberration-corrected JEOL ARM-200CF scanning transmission electron microscope operating at $200 \mathrm{kV}$. This microscope was also equipped with a Centurio silicon drift detector (SDD) system for X-ray energy-dispersive spectroscopy (XEDS) analysis.

Catalytic Testing Experiments: Activity and Deactivation Measurements. The 1 wt $\%$ and the 2 wt \% Au/C-AR catalysts were tested using a completely automated reactor system with the same setup as previously described. ${ }^{8}$ All of the predilute gases $5 \% \mathrm{C}_{2} \mathrm{H}_{2} / \mathrm{Ar}$ (BOC), $5 \% \mathrm{HCl} / \mathrm{Ar} \mathrm{BOC}$ ), and $\mathrm{Ar}$ (99.99\% BIP, Air Products) were dried using moisture traps before being introduced into the reactor. In all cases the reactor was heated to $200^{\circ} \mathrm{C}$ at a ramp rate of $5{ }^{\circ} \mathrm{C} / \mathrm{min}$ and held at this temperature for $30 \mathrm{~min}$ under a flow of argon prior to admitting the hydrochlorination reaction mixture. The tests were performed using a fixed-bed polyimide (Kapton) microreactor containing the catalysts, keeping the total flow of $50 \mathrm{~mL} \mathrm{~min}^{-1}$ and a total gas hourly space velocity (GHSV) of $\sim 14000 \mathrm{~h}^{-1}$. When both reactants were present, the $\mathrm{C}_{2} \mathrm{H}_{2}: \mathrm{HCl}$ ratio was kept at a constant value of $1: 1.02$. 
The sequential flow experiment (reaction sequence 1) was performed using the $1 \% \mathrm{Au} / \mathrm{C}$-AR catalyst while simultaneously monitoring the $\mathrm{Au} \mathrm{L}_{3}$-edge XAFS and catalytic activity.

Reaction sequence 1 employed the following gas compositions: step i $=\mathrm{HCl} / \mathrm{C}_{2} \mathrm{H}_{2} / \mathrm{Ar}$, step ii $=\mathrm{HCl} / \mathrm{Ar}$, step iii $=\mathrm{HCl}$ / $\mathrm{C}_{2} \mathrm{H}_{2} / \mathrm{Ar}$, step iv $=\mathrm{C}_{2} \mathrm{H}_{2} / \mathrm{Ar}$, and step $\mathrm{v}=\mathrm{HCl} / \mathrm{C}_{2} \mathrm{H}_{2} / \mathrm{Ar}$.

The duration of each step in the sequence was not the same. The gas composition during the experiment was altered only when no further change in the XAFS spectra was observed. For this reason, the duration of each step in the reaction sequence was as follows: step $i=240 \mathrm{~min}$, step $i \mathrm{i}=75 \mathrm{~min}$, step iii $=120 \mathrm{~min}$, step iv $=70 \mathrm{~min}$, and step $\mathrm{v}=90 \mathrm{~min}$.

The reaction mixture was analyzed online by mass spectrometry (Hiden QGA), and Professional Edition software was used for both qualitative and quantitative analyses. The catalyst activity presented is shown in terms of productivity toward vinyl chloride monomer (VCM). The response factor of the mass spectrometer toward VCM was correlated with the productivity $\left(\mathrm{mol} \mathrm{kg}_{\mathrm{cat}}{ }^{-1} \mathrm{~h}^{-1}\right)$ obtained by using a Varian 450 gas chromatograph equipped with a flame ionization detector (FID). Chromatographic separation and identification of the products was carried out using a Porapak N packed column $\left(6 \mathrm{ft} \times 1 / 8^{\prime \prime}\right.$ stainless steel $)$. Using the correlation obtained between productivity and VCM mass spectrometer response, it was possible to deduce the productivity for the catalytic reactions performed.

Determination of Orders of Reaction with Respect to the Reactant Gases. The reactions were performed using the same reactor setup as described above. The reaction mixture before and after reaction was analyzed by gas chromatography. The results are presented in terms of acetylene conversion (\%). The following reaction conditions were employed: mass of catalyst $0.045 \mathrm{~g}$; temperature $200{ }^{\circ} \mathrm{C}$; total flow of gases $50 \mathrm{~mL} / \mathrm{min}$; gas makeup $5 \% \mathrm{C}_{2} \mathrm{H}_{2} / \mathrm{Ar}, 5 \% \mathrm{HCl} / \mathrm{Ar}, \mathrm{Ar}$; initial gas concentrations $2.30 \% \mathrm{C}_{2} \mathrm{H}_{2} / \mathrm{Ar}, 2.35 \% \mathrm{HCl} / \mathrm{Ar}$. The concentration of $\mathrm{C}_{2} \mathrm{H}_{2} / \mathrm{Ar}$ was then altered (from $\% \mathrm{C}_{2} \mathrm{H}_{2} / \mathrm{Ar}=0.23-$ 0.29-0.35-0.41-0.47) maintaining constant the concentration of $\mathrm{HCl} / \mathrm{Ar}$ or the concentration of $\mathrm{HCl} / \mathrm{Ar}$ was changed (\% $\mathrm{HCl} / \mathrm{Ar}=0.90-1.60-2.35-3.10)$ maintaining a constant concentration of acetylene/Ar.

\section{ASSOCIATED CONTENT}

\section{(5) Supporting Information}

The Supporting Information is available free of charge on the ACS Publications website at DOI: 10.1021/acscatal.8b02232.

Information about the data underpinning the results presented here, including how to access them, can be found in the Cardiff University data catalogue at http:// doi.org/10.17035/d.2018.0054961412

Effect of the $\mathrm{Au}(0)$ contribution in the correlation between white line height and $\mathrm{Au}(\mathrm{III}) / \mathrm{Au}(\mathrm{I})$ ratio, further EXAFS data of the 1 wt $\% A u / C-A R$ catalyst during the sequential gas experiment, XRD/XAFS/ STEM/INS characterization of the freshly prepared and used 2 wt \% Au/C-AR catalyst, proposed models for INS data spectra simulations (PDF)

\section{AUTHOR INFORMATION}

\section{Corresponding Author}

*E-mail: Hutch@Cardiff.ac.uk.

ORCID $\odot$

S. A. Kondrat: 0000-0003-4972-693X

X. Liu: 0000-0002-8654-0774
L. Lu: 0000-0002-6688-1176

E. K. Gibson: 0000-0002-7839-3786

P. P. Wells: 0000-0002-0859-9172

S. F. Parker: 0000-0002-3228-2570

G. J. Hutchings: 0000-0001-8885-1560

Notes

The authors declare no competing financial interest.

\section{ACKNOWLEDGMENTS}

The authors thank Cardiff University for support as part of the MAXNET Energy Consortium. The UK Catalysis Hub is thanked for resources and support provided through our membership of the UK Catalysis Hub Consortium and funded by the Engineering and Physical Sciences Research Council (EPSRC) (grants EP/K014706/1, EP/K014668/1, EP/ $\mathrm{K} 014854 / 1 \mathrm{EP} / \mathrm{K} 014714 / 1$, and EP/M013219/1). We used the B18 beamline at the Diamond Light Source (allocation numbers SP10306, SP11398, and SP15214) with the help of D. Gianolio and G. Cibin. We gratefully acknowledge the Science and Technology Facilities Council (STFC) for access to neutron beamtime at ISIS and also for the provision of sample preparation, Merlin facilities. C.J.K. acknowledges funding from the National Science Foundation Major Research Instrumentation program (GR no. MRI/DMR-1040229). We thank Johnson Matthey for their contribution to and funding of this work. We thank S. Morris for technical support.

\section{REFERENCES}

(1) Agnew, J. B.; Shankar, H. S. Catalyst Deactivation in Acetylene Hydrochlorination. Ind. Eng. Chem. Prod. Res. Dev. 1986, 25 (1), 1922.

(2) Bremer, H.; Lieske, H. Kinetics of the Hydrochlorination of Acetylene on $\mathrm{HgCl}_{2} /$ Active Carbon Catalysts. Appl. Catal. 1985, 18 (1), 191-203.

(3) Hutchings, G. J.; Grady, D. T. Effect of Drying Conditions on Carbon Supported Mercuric Chloride Catalysts. Appl. Catal. 1985, 16 (3), 411-415.

(4) Hutchings, G. J.; Grady, D. T. Hydrochlorination of Acetylene: The Effect of Mercuric Chloride Concentration on Catalyst Life. Appl. Catal. 1985, 17 (1), 155-160.

(5) Hutchings, G. J. Vapor Phase Hydrochlorination of Acetylene: Correlation of Catalytic Activity of Supported Metal Chloride Catalysts. J. Catal. 1985, 96 (1), 292-295.

(6) Johnston, P.; Carthey, N.; Hutchings, G. J. Discovery, Development, and Commercialization of Gold Catalysts for Acetylene Hydrochlorination. J. Am. Chem. Soc. 2015, 137 (46), 14548-14557.

(7) Conte, M.; Carley, A. F.; Heirene, C.; Willock, D. J.; Johnston, P.; Herzing, A. A.; Kiely, C. J.; Hutchings, G. J. Hydrochlorination of Acetylene Using a Supported Gold Catalyst: A Study of the Reaction Mechanism. J. Catal. 2007, 250 (2), 231-239.

(8) Liu, X.; Conte, M.; Elias, D.; Lu, L.; Morgan, D. J.; Freakley, S. J.; Johnston, P.; Kiely, C. J.; Hutchings, G. J. Investigation of the Active Species in the Carbon-Supported Gold Catalyst for Acetylene Hydrochlorination. Catal. Sci. Technol. 2016, 6 (13), 5144-5153.

(9) Malta, G.; Kondrat, S. A.; Freakley, S. J.; Davies, C. J.; Lu, L.; Dawson, S.; Thetford, A.; Gibson, E. K.; Morgan, D. J.; Jones, W.; Wells, P. P.; Johnston, P.; Catlow, C. R. A.; Kiely, C. J.; Hutchings, G. J. Identification of Single-Site Gold Catalysis in Acetylene Hydrochlorination. Science 2017, 355 (6332), 1399-1403.

(10) Fong, Y. Y.; Visser, B. R.; Gascooke, J. R.; Cowie, B. C. C.; Thomsen, L.; Metha, G. F.; Buntine, M. A.; Harris, H. H. Photoreduction Kinetics of Sodium Tetrachloroaurate under Synchrotron Soft X-Ray Exposure. Langmuir 2011, 27 (13), 8099-8104. 
(11) Ozkaraoglu, E.; Tunc, I.; Suzer, S. X-Ray Induced Reduction of $\mathrm{Au}$ and Pt Ions on Silicon Substrates. Surf. Coat. Technol. 2007, 201 (1920), 8202-8204.

(12) Ozkaraoglu, E.; Tunc, I.; Suzer, S. Preparation of Au and Au-Pt Nanoparticles within PMMA Matrix Using UV and X-Ray Irradiation. Polymer 2009, 50 (2), 462-466.

(13) Karadas, F.; Ertas, G.; Ozkaraoglu, E.; Suzer, S. X-Ray-Induced Production of Gold Nanoparticles on a $\mathrm{SiO} 2 / \mathrm{Si}$ System and in a Poly(Methyl Methacrylate) Matrix. Langmuir 2005, 21 (1), 437-442.

(14) Kitagawa, H.; Kojima, N.; Matsushita, N.; Ban, T.; Tsujikawa, I. Studies of Mixed-Valence States in Three-Dimensional HalogenBridged Gold Compounds, $\mathrm{Cs}_{2} \mathrm{Au}^{\mathrm{I}} \mathrm{Au}^{\mathrm{III}} \mathrm{X}_{6}(\mathrm{X}=\mathrm{Cl}, \mathrm{Br}$ or I $)$. Part 1 . Synthesis, X-Ray Powder Diffraction, and Electron Spin Resonance Studies of $\mathrm{CsAu}_{0.6} \mathrm{Br}_{2.6}$. J. Chem. Soc., Dalton Trans. 1991, 0 (11), 31153119.

(15) Kitagawa, H.; Kojima, N.; Nakajima, T. Studies of MixedValence States in Three-Dimensional Halogen-Bridged Gold Compounds, $\mathrm{Cs}_{2} \mathrm{Au}^{\mathrm{I}} \mathrm{Au}^{\mathrm{III}} \mathrm{X}_{6},(\mathrm{X}=\mathrm{Cl}, \mathrm{Br}$ or I). Part 2. X-Ray Photoelectron Spectroscopic Study. J. Chem. Soc., Dalton Trans. 1991, 0 (11), 31213125.

(16) Nkosi, B.; Adams, M. D.; Coville, N. J.; Hutchings, G. J. Hydrochlorination of Acetylene Using Carbon-Supported Gold Catalysts: A Study of Catalyst Reactivation. J. Catal. 1991, 128 (2), 378-386.

(17) Dai, B.; Wang, Q.; Yu, F.; Zhu, M. Effect of Au Nano-Particle Aggregation on the Deactivation of the $\mathrm{AuCl}_{3} / \mathrm{AC}$ Catalyst for Acetylene Hydrochlorination. Sci. Rep. 2015, 5 (1), 10553.

(18) Zhang, H.; Dai, B.; Wang, X.; Li, W.; Han, Y.; Gu, J.; Zhang, J. Non-Mercury Catalytic Acetylene Hydrochlorination over Bimetallic $\mathrm{Au}-\mathrm{Co}(\mathrm{III}) / \mathrm{SAC}$ Catalysts for Vinyl Chloride Monomer Production. Green Chem. 2013, 15 (3), 829.

(19) Zhu, M.; Wang, Q.; Chen, K.; Wang, Y.; Huang, C.; Dai, H.; Yu, F.; Kang, L.; Dai, B. Development of a Heterogeneous Non-Mercury Catalyst for Acetylene Hydrochlorination. ACS Catal. 2015, 5 (9), 5306-5316.

(20) Nkosi, B.; Coville, N. J.; Hutchings, G. J.; Adam, M. D.; Friedl, J. Hydrochlorination of Acetylene Using Gold Catalysts: A Study of Catalyst Deactivation. J. Catal. 1991, 128 (2), 366-377.

(21) Friedl, J.; Wagner, F. E.; Nkosi, B.; Towert, M.; Coville, N. J.; Adams, M. D.; Hutchings, G. J. ${ }^{197} A u$ Mössbauer Study of the Deactivation and Reactivation of a Carbon-Supported AuCl4 Hydrochlorination Catalyst. Hyperfine Interact. 1992, 69 (1-4), $767-770$.

(22) Conte, M.; Carley, A. F.; Hutchings, G. J. Reactivation of a Carbon-Supported Gold Catalyst for the Hydrochlorination of Acetylene. Catal. Lett. 2008, 124 (3-4), 165-167.

(23) Conte, M.; Davies, C. J.; Morgan, D. J.; Davies, T. E.; Carley, A. F.; Johnston, P.; Hutchings, G. J. Modifications of the Metal and Support during the Deactivation and Regeneration of $\mathrm{Au} / \mathrm{C}$ Catalysts for the Hydrochlorination of Acetylene. Catal. Sci. Technol. 2013, 3 (1), $128-134$.

(24) Nkosi, B.; Coville, N. J.; Hutchings, G. J. Reactivation of a Supported Gold Catalyst for Acetylene Hydrochlorination. J. Chem. Soc., Chem. Commun. 1988, 0 (1), 71-72.

(25) Pouwer, R. H.; Williams, C. M.; Raine, A. L.; Harper, J. B. OneStep" Alkynylation of Adamantyl Iodide with Silver(I) Acetylides. Org. Lett. 2005, 7 (7), 1323-1325.

(26) Pouwer, R. H.; Harper, J. B.; Vyakaranam, K.; Michl, J.; Williams, C. M.; Jessen, C. H.; Bernhardt, P. V. Investigating Direct Alkynylation at the Bridgehead of Bicyclic Cages Using Silver(I) Acetylides. Eur. J. Org. Chem. 2007, 2007 (2), 241-248.

(27) Han, F.; Li, J.; Zhang, H.; Wang, T.; Lin, Z.; Xia, H. Reactions of Osmabenzene with Silver/Copper Acetylides: From Metallabenzene to Benzene. Chem. - Eur. J. 2015, 21 (2), 565-567.

(28) Castro, C. E.; Havlin, R.; Honwad, V. K.; Malte, A.; Moje, S. Copper(I) Substitutions. Scope and Mechanism of Cuprous Acetylide Substitutions. J. Am. Chem. Soc. 1969, 91 (23), 6464-6470.

(29) Bertus, P.; Fécourt, F.; Bauder, C.; Pale, P. Evidence for the in Situ Formation of Copper Acetylides during $\mathrm{Pd} / \mathrm{Cu}$ Catalyzed
Synthesis of Enynes: A New Synthesis of Allenynols. New J. Chem. 2004, 28 (1), 12-14.

(30) Simonneau, A.; Jaroschik, F.; Lesage, D.; Karanik, M.; Guillot, R.; Malacria, M.; Tabet, J.-C.; Goddard, J.-P.; Fensterbank, L.; Gandon, V.; Gimbert, Y. Tracking Gold Acetylides in Gold(I)-Catalyzed Cycloisomerization Reactions of Enynes. Chem. Sci. 2011, 2 (12), 24172422.

(31) Hashmi, A. S. K. Gold-Catalyzed Organic Reactions GoldCatalyzed Organic Reactions. Chem. Rev. 2007, 107, 3180-3211.

(32) Li, Z.; Brouwer, C.; He, C. Gold-Catalyzed Organic Transformations. Chem. Rev. 2008, 108 (8), 3239-3265.

(33) Schmidbaur, H.; Schier, A. Gold $\eta^{2}$-Coordination to Unsaturated and Aromatic Hydrocarbons: The Key Step in Gold-Catalyzed Organic Transformations. Organometallics 2010, 29 (1), 2-23.

(34) Corma, A.; Leyva-Pérez, A.; Sabater, M. J. Gold-Catalyzed Carbon-Heteroatom Bond-Forming Reactions. Chem. Rev. 2011, 111 (3), 1657-1712.

(35) Hirata, S.; Torii, H.; Furukawa, Y.; Tasumi, M.; Tomkinson, J. Inelastic Neutron Scattering from Trans-Polyacetylene. Chem. Phys. Lett. 1996, 261 (3), 241-245.

(36) Ravel, B.; Newville, M. ATHENA, ARTEMIS, HEPHAESTUS: Data Analysis for X-Ray Absorption Spectroscopy Using IFEFFIT. J. Synchrotron Radiat. 2005, 12, 537-541.

(37) Newville, M. IFEFFIT: Interactive XAFS Analysis and FEFF Fitting. J. Synchrotron Radiat. 2001, 8 (2), 322-324.

(38) Bewley, R. I.; Eccleston, R. S.; McEwen, K. A.; Hayden, S. M.; Dove, M. T.; Bennington, S. M.; Treadgold, J. R.; Coleman, R. L. S. MERLIN, a New High Count Rate Spectrometer at ISIS. Phys. B 2006, 385-386, 1029-1031.

(39) Sheppard, N.; De La Cruz, C. Vibrational Spectra of Hydrocarbons Adsorbed on Metals. Part II. Adsorbed Acyclic Alkynes and Alkanes, Cyclic Hydrocarbons Including Aromatics and Surface Hydrocarbon Groups Derived from the Decomposition of Alkyl Halides, Etc. Adv. Catal. 1998, 42, 181-313.

(40) Dymkowski, K.; Parker, S. F.; Fernandez-Alonso, F.; Mukhopadhyay, S. AbINS: The Modern Software for INS Interpretation. Phys. B 2018, DOI: 10.1016/j.physb.2018.02.034. 